\title{
Geochemistry of Evaporites in Lacustrine Basin, Dongying Depression, Bohai Bay Basin, China
}

\author{
Zhonghong Chen ${ }^{1 *}$, Jiqing Zhang ${ }^{2}$, Li Wang ${ }^{2}$ and Ming Zha ${ }^{1}$ \\ ${ }^{1}$ School of Geosciences, China University of Petroleum, Qingdao, Shandong, China \\ ${ }^{2}$ Petroleum Developing Center in Shengli Oilfield, SINOPEC, Dongying, Shandong, China
}

\begin{abstract}
The middle and lower parts of the Fourth Member of the Shahejie Formation in the Dongying Depression are representatives of evaporites and mud rocks in Eastern China. To investigate hydrocarbon potential, some deep wells, such as the Hk1 well and Fs2 well, were intensively cored and evaluated by geochemistry.

The total salinity of the formation waters is very high and is dominated by $\mathrm{CaCl}_{2}$, suggesting favorable seal development and preservation of petroleum. The content of $\mathrm{Al}, \mathrm{Mn}$, and $\mathrm{Ba}$ and the ratios of $\mathrm{V} / \mathrm{Ni}$ and $(\mathrm{Fe}+\mathrm{Al}) /(\mathrm{Ca}+\mathrm{Mg})$ were low, whereas the content of $\mathrm{Na}, \mathrm{Ca}$, and $\mathrm{Mg}$ and the ratios of $\mathrm{Sr} / \mathrm{Ba}, \mathrm{Fe} / \mathrm{Mn}$, and $\mathrm{Sr} / \mathrm{Ca}$ were high in the evaporites and mudstones of the $\mathrm{Fourth} \mathrm{Member}$ compared with those in the mudstones of the Third Member. Sr content was remarkably high. The co-sedimentary system of evaporites and mudstones displays a heavier isotope of carbon. The values of $\delta^{13} \mathrm{C}$ for different group compositions and n-alkanes ranged from $-28 \%$ to $-21 \%$ and $-18 \%$ to $-32 \%$, the fractionation of $\delta^{13} \mathrm{C}$ between group compositions was no greater than $-2 \%$, and $\delta^{13} \mathrm{C}$ of $\mathrm{C}_{17}$ and $\mathrm{C}_{18}$ significantly fluctuated. $\delta^{13} \mathrm{C}$ for high-maturity evaporite source rocks was significantly increased by thermal evolution and thermochemical sulfate reduction. High content of gammacerane and low $\mathrm{Pr} / \mathrm{Ph}$ was exhibited in the evaporite system compared with that in the non-evaporite system. Different responses of biomarker parameters for the different sedimentary systems were exhibited, such as $C_{19} /\left(C_{19}+C_{23}\right)$ terpanes, $C_{29} /\left(C_{27}+C_{28}+C_{29}\right)$ steranes, and $C_{24} / C_{23}$ and $C_{22} / C_{21}$ tricyclic terpanes. The reverse trend of the maturation parameters at depths corresponding to abundant carbonate minerals indicates that carbonate retards the thermal evolution of organic matter. Evaporites and mudstones can generate and expel hydrocarbons. The tested samples were mostly types I and $\mathrm{II}_{1}$ of organic matter, and their original generating capacity can reach 40 and $20 \mathrm{mg} / \mathrm{g}$ rock, respectively. The efficiency of hydrocarbon expulsion reached $60 \%$, but the distribution of organic matter and its generative potential were highly variable. In general, the mudstones show greater generative potential than the evaporites.
\end{abstract}

Keywords: Mineral element; Carbon isotope; Evaporite; Hydrocarbon generation; Hydrocarbon expulsion; Dongying depression

\section{Introduction}

The formation, physical properties [1-4] and hydrocarbon potential of evaporites and mudstones has always been of interest to the petroleum industry [5,6]. Evaporite rocks are widely developed in petroliferous basins around the world and closely relate to the formation and distribution of the global giant oil and gas fields. Specifically in China evaporites are widespread in some Tertiary rifted lacustrine basins (Figure 1). For instance, the Jiyang, Jizhong, Dongpu, and Qianjiang Depressions are all piled with organic-rich gypsum-salt rocks and mudstones and form typical co-sedimentary systems. High bio-productivity in evaporite sedimentary environments that contain carbonate, sulfate, or chloride salt accumulates organic-rich sediment that may serve as source rocks [7-9].

The Dongying depression is a typical lacustrine basin containing evaporites and mudstones in eastern China. Dark mudstone is mainly deposited in the upper part of Member $4\left(\mathrm{Es}_{4}\right)$ and the lower and middle parts of Member 3(Es $)$ of the Shahejie Formation in the Paleogene system; these parts are regarded as main hydrocarbon source rocks in the Depression [10-13]. However, exploration for many wells in the northern slope of the Depression has generated high-yield oil and gas from the evaporites and mudstones in the middle part of Member 4. This yield is a favorable prospect for oil and gas exploration and thus arouses considerable concern regarding evaporites and mudstones $[9$, 13]. However, the geochemistry of evaporites and mudstones has rarely been investigated for fewer wells drilled through deeply buried source rocks. Exploration has carried out few deep drillings, such as the Hao-1 Well and Fs2 well. On this basis, more intensive coring and calculating was conducted to study the geochemistry of evaporites and mudstones.

The study primarily aims to (1) better understand the response of mineral elements and related ratios in a saline lacustrine compared with those in a fresh lacustrine, (2) define the response of $\delta^{13} \mathrm{C}$ in a saline lacustrine, (3) improve understanding of biomarkers in a saline lacustrine, and (4) determine the capacity of evaporites to generate and expel hydrocarbon.

\section{Geological Setting and Evaporite Distribution}

The Dongying Depression is a typical negative rifted tectonic unit located in the southern part of the Bohai Bay Basin and characterized as northern faulted, southern overlapped, and opening-shaped. The depression developed from ancient Paleozoic bedrock with various tectonic movements, covering an area of $5700 \mathrm{~km}^{2}$.

A set of clastic materials is deposited in the Paleogene system and is dominated by mudstone intermixed with sandstone, carbonate, and gypsum-salt rocks. Under the impact of tectonic movement, the sediment has undergone a sedimentary process in three different stages: salted lake, deep lacustrine, and river delta. In the process, the main source rocks deposited in this depression are $\mathrm{E} s_{4}$, deposited at a hypersaline environment, and $\mathrm{E} s_{3}$, deposited at a fresh-brackish environment.

*Corresponding author: Chen Zhonghong, School of Geosciences, China University of Petroleum, Qingdao, 266580, Shandong, China, E-mail hongczh@163.com

Received August 20, 2013; Accepted September 27, 2013; Published October 04, 2013

Citation: Chen ZH, Zhang JQ, Wang L, Zha M (2013) Geochemistry of Evaporites in Lacustrine Basin, Dongying Depression, Bohai Bay Basin, China. J Pet Environ Biotechnol 4: 156. doi:10.4172/2157-7463.1000156

Copyright: (c) 2013 Zhonghong C, et al. This is an open-access article distributed under the terms of the Creative Commons Attribution License, which permits unrestricted use, distribution, and reproduction in any medium, provided the original author and source are credited. 

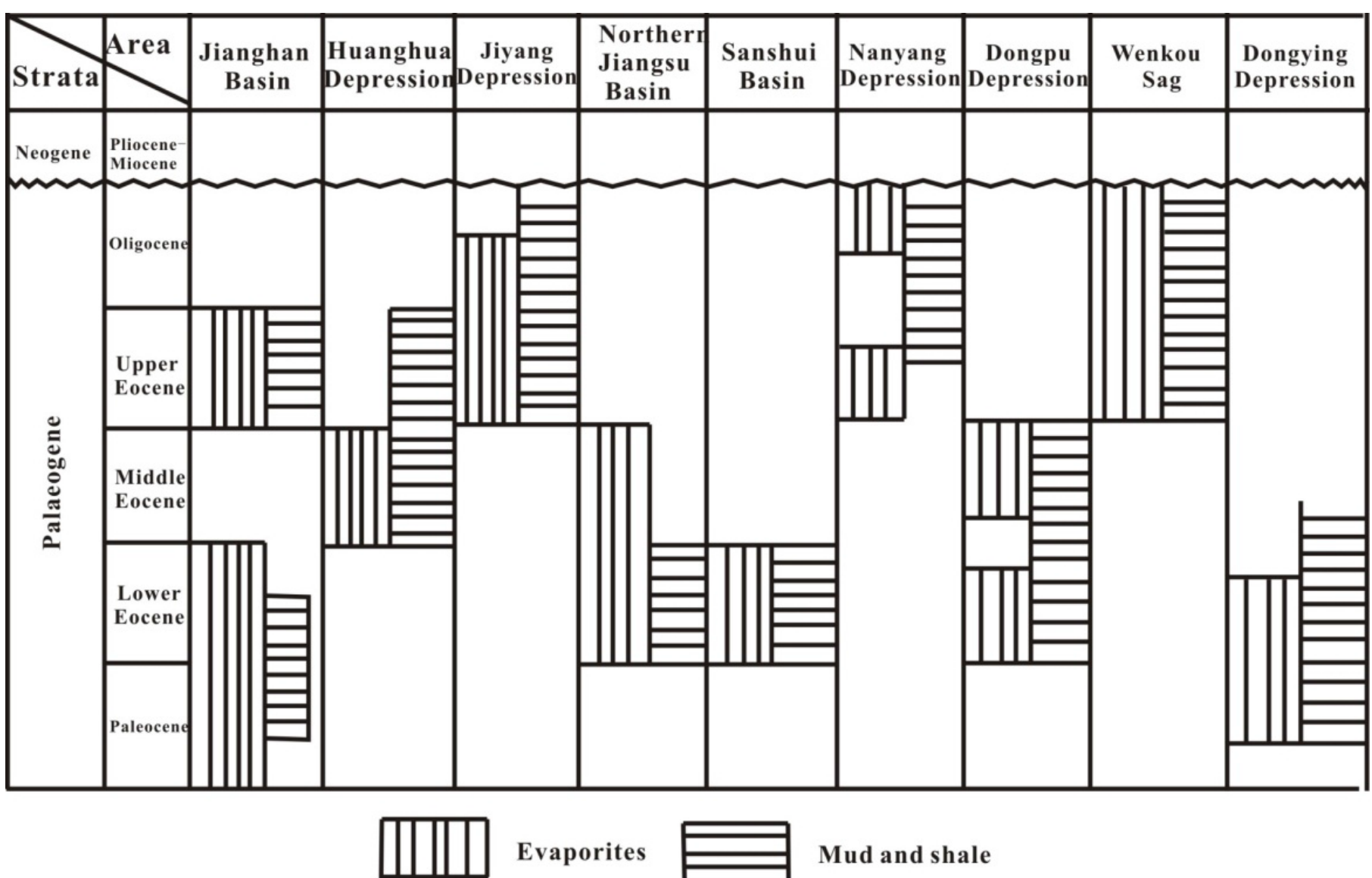

Evaporites

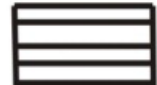

Mud and shale

Figure 1: The distribution of the evaporates and mudstone in the Tertiary lacustrine basins in China.

In the lower part of $\mathrm{E} s_{4}$, some brine-lake sediment, including gray shale, oil shale, salt rock, gypsum, and alluvial fan, is deposited in an evaporiting environment under weak tectonic activity and extremely hot and dry climate (Figures 2 and 3). In the central part of the lake during this period can be found about $400 \mathrm{~m}$ to $600 \mathrm{~m}$ of thick gray mudstone with salt rock and gypsum layers. In mid-E $s_{4}$ deposition, tectonic subsidence significantly increased, and a large rifted lake formed between high and continuous mountains. A large amount of lake water evaporated with result of high salinity. The highly saline center $(>100 \mathrm{~g} / \mathrm{l})$ is distributed in the Minfeng sag of the northern basin, coinciding with the evaporite distribution (Figure 4). The salinity increased from the edge to the center of the salt lake, and some shales, marls, plasters, salts, and mudstones were deposited in sequence. In the alternation of oxygen environments with hypoxic environments, co-sediment of evaporites and mudstones was formed.

\section{Experiment Methods}

The contents of inorganic elements were measured by conventional ICP-AES and atomic absorption spectra in well drilling. Formation pressure and temperature were obtained by related testers in the drilling.

Sediment samples were crushed in a rotary mill, and aliquots were subjected to rock-eval pyrolysis to determine total organic carbon content, residual soluble hydrocarbon $\left(S_{1}\right)$, pyrolysed hydrocarbon $\left(S_{2}\right)$, production index, and hydrogen index $\left(I_{\mathrm{H}}\right), T_{\max }$ (temperature of maximum kerogen pyrolysate yield). Vitrinite reflectance
$\left(R_{\mathrm{o}}\right)$ was analyzed on randomly oriented grains by conventional microphotometric methods.

Chloroform is used as a solvent, and the samples are continuously extracted for $72 \mathrm{~h}$ at a constant temperature of $70^{\circ} \mathrm{C}$ in a Soxhlet extraction device. Ten to 15 milligrams of the samples were extracted, dissolved by petroleum ether, repeatedly washed, and moved in a flask, standing for $24 \mathrm{~h}$ (about $100 \mathrm{ml}$ of petroleum ether in flask). The solution was finally filtered. The insoluble part was asphaltene, and the soluble part was a mixture of saturated hydrocarbons, aromatic hydrocarbons, and non-hydrocarbons.

A prepared filling column of silica-alumina and alumina was activated for $5 \mathrm{~h}$ at a constant temperature of $450^{\circ} \mathrm{C}$, and silica was activated for $8 \mathrm{~h}$ at a constant temperature of $150^{\circ} \mathrm{C}$. Filled column chromatography was conducted with the silica and alumina at a ratio of 3:1 (silica in the up of alumina). After the column was wet with petroleum ether, the sample filtrate was poured into the column and washed with petroleum ether, dichloromethane, and diethyl ether. Saturated hydrocarbons, aromatic hydrocarbons, and nonhydrocarbons were then obtained.

HP-Chemistation was used as a GC-MS analytical instrument (model: HP-5890 II type for GC, HP-5890A for MS; column: DB5MS; column length: $60 \mathrm{~m}$; internal diameter: $0.25 \mathrm{~mm}$ ). The initial temperature was $100^{\circ} \mathrm{C}$, the heating rate was $4^{\circ} \mathrm{C} / \mathrm{min}$, the final temperature was $320^{\circ} \mathrm{C}$, and the final time was $20 \mathrm{~min}$. The temperature of gasification and transmission pipeline was $310^{\circ} \mathrm{C}$, the ion source 


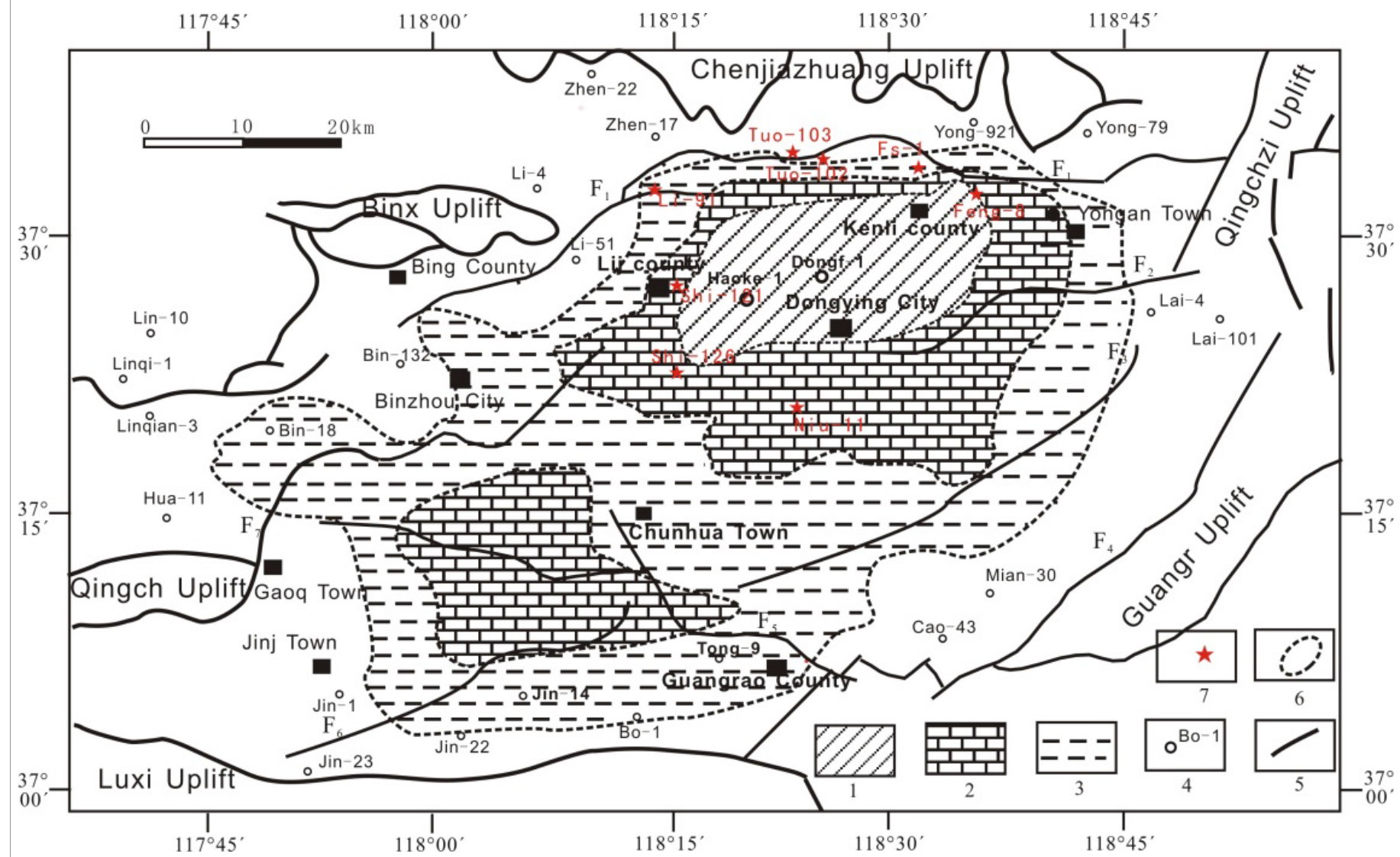

Figure 2: Sketch map showing the distribution of the co-sedimentary system of evaporites and source rocks in the middle part of Member 4 of the Shahejie Formation in the Dongying depression.

1. halite, gypsum; 2 limestone, dolomite; 3 . mudstone; 4 . wells; 5 . faults; 6 . boundary of different sedimentary systems; 7 . the Wells for the samples coring.

temperature was $250^{\circ} \mathrm{C}$, and the pre-column pressure was $170 \mathrm{kPa}$. The split ratio was 20:1, and the carrier gas was helium. Electron energy was $70 \mathrm{eV}$, the scan rate was $0.46 \mathrm{scans} / \mathrm{s}$, and ionization was conducted by electronic impact.

Biomarkers were identified on the basis of mass fragment graphic responses and relative retention times, compared with a standard sample. Quantification was conducted by peak height responses in specific mass chromatograms, such as the $\mathrm{m} / \mathrm{z} 191$ and $\mathrm{m} / \mathrm{z} 217$ mass chromatograms.

The $\delta^{13} \mathrm{C}$ values for $\mathrm{n}$-alkanes were obtained by a Finnigan Mat GC-IRMS with a delta-S mass spectrometer. In a typical analysis, $1 \mu \mathrm{l}$ of n-alkane concentrate was injected into a DB- 5 chemically bonded fused silica capillary column $(30 \mathrm{~m} \times 0.32 \mathrm{~mm}$ i.d. $)$ with splitless mode. Helium was used as a carrier gas. The GC oven temperature was programmed from $60^{\circ} \mathrm{C}$ to $120^{\circ} \mathrm{C}$ at $30^{\circ} \mathrm{C} \mathrm{min}{ }^{-1}$ and then to $310^{\circ} \mathrm{C}$ at $5^{\circ} \mathrm{C} \mathrm{min}^{-1}$. Injector temperature was $300^{\circ} \mathrm{C}$. The measurement was conducted three or four times in most cases.

\section{Results and Discussion}

\section{Inorganic elements in evaporites}

In evaporate system the hydrocarbon generation is often associated with certain metals. For example, sulfate reducing agent can extract metal ions from salt water, and some metal ions can be selectively absorbed by the algae and higher aquatic plants around, which are released from decomposition of organic matter later. Amino acids generated from organic matter may improve the solubility of heavy metals. Therefore, the inorganic elements can reflect the sedimentary environment, water-rock interaction and hydrocarbon fluid flow.

The cores in the Paleogene system from the Hk1 Well were tested intensively and analyzed to investigate the inorganic elements of the evaporites and mudstone and to contrast the distribution rules for different sedimentary environments. The evaporites in $\mathrm{E} s_{4}$ have low $\mathrm{Al}$ content (average $=3.49 \%$ ) but high $\mathrm{Na}, \mathrm{Ca}$, and $\mathrm{Mg}$ content (average $=7.03 \%, 10.11 \%, 2.68 \%$, respectively) compared with the mudstone in $\mathrm{Es}_{3}$. Among the trace elements, $\mathrm{Mn}$ and $\mathrm{Ba}$ in the evaporites have significantly low content (average $=697.9 \times 10^{-6}$ and $473.6 \times 10^{-6}$, respectively), whereas $\mathrm{Sr}$ content is remarkably high (average $=1135.35$ $\left.\times 10^{-6}\right)$. The ratios $\mathrm{V} / \mathrm{Ni}$ and $(\mathrm{Fe}+\mathrm{Al}) /(\mathrm{Ca}+\mathrm{Mg})$ are low (average $=1.99$ and 0.60 , respectively), whereas the ratios $\mathrm{Sr} / \mathrm{Ba}, \mathrm{Fe} / \mathrm{Mn}$, and $\mathrm{Sr} / \mathrm{Ca}$ are high (average $=3.99,85.59$, and 0.019, respectively). Particularly, the Sr/ $\mathrm{Ba}$ ratio in the $\mathrm{Es} s_{4}$ evaporite system is five times that in the $\mathrm{Es} s_{3}$ nonevaporite system.

The chemical field of formation water also reflects the strong response of some major rock-forming elements in the evaporite system. Rock-forming elements sodium $(\mathrm{Na})$, calcium $(\mathrm{Ca})$, and magnesium $(\mathrm{Mg})$ are the main cations in formation water, and their contents are well correlated with salinity. The salinity in the evaporite system is remarkably high, ranging from $1.63 \mathrm{~g} / \mathrm{l}$ to $335.50 \mathrm{~g} / \mathrm{l}$ and averaging 63.3 $\mathrm{g} / \mathrm{l}$.

The distribution of inorganic elements in the evaporites and 
Citation: Chen ZH, Zhang JQ, Wang L, Zha M (2013) Geochemistry of Evaporites in Lacustrine Basin, Dongying Depression, Bohai Bay Basin, China J Pet Environ Biotechnol 4: 156. doi:10.4172/2157-7463.1000156

Page 4 of 15
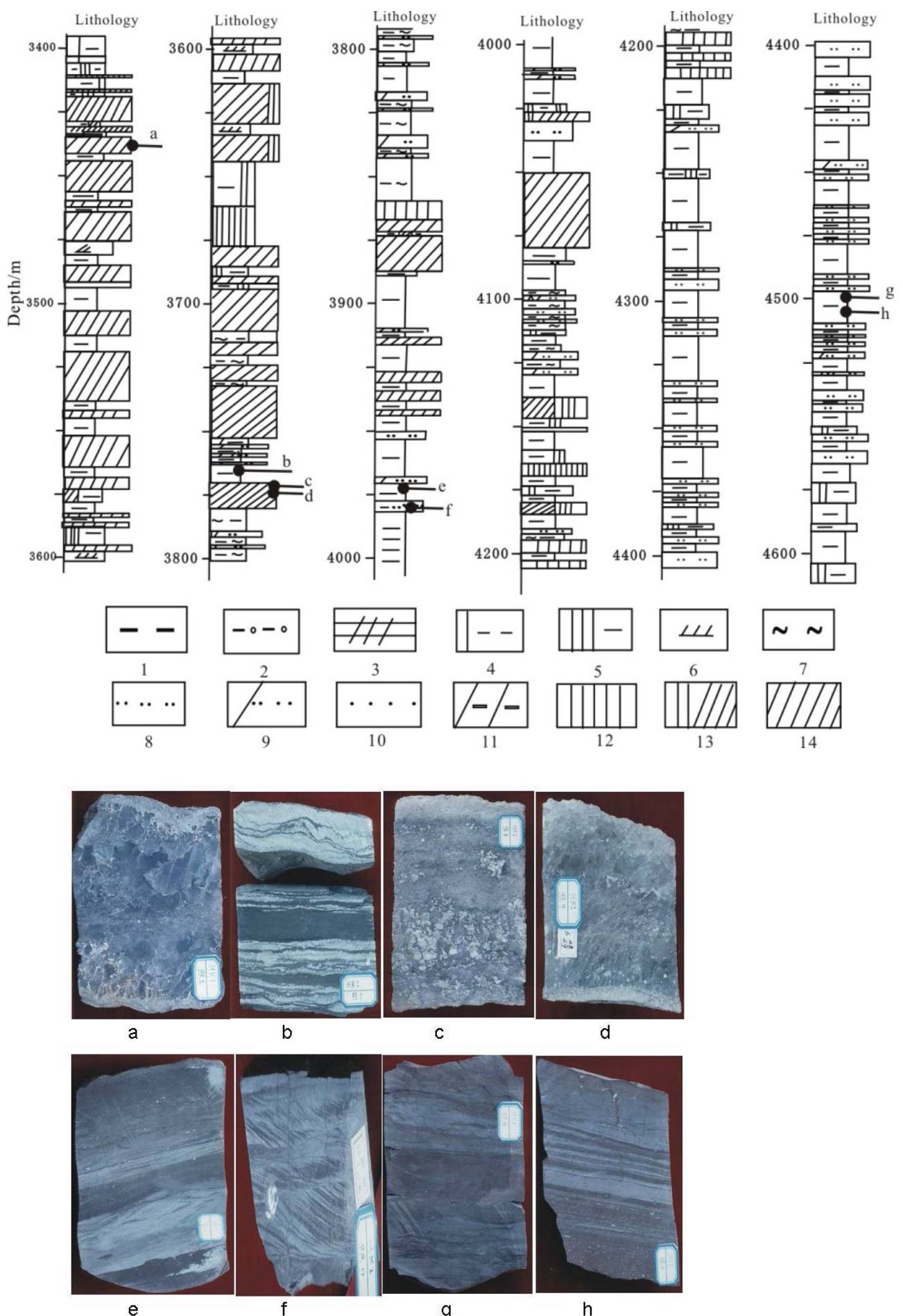

Figure 3: The lithologic log of the co-sedimentary system of evaporites and mudstone and their representative photos in the Es4 from Hk1 Well in Dongying depression a: $3438.48 \mathrm{~m}$, salt rock, salt grain in the middle is larger than the edge of the salt rock.

b:3769.65m, dark gray mudstone with thin layers of salt and a deformation of bedding.

c: $3771.45 \mathrm{~m}$, salt rock with two rhythmic.

d: $3772.2 \mathrm{~m}$, salt rock with three rhythmics

e: $3972.1 \mathrm{~m}$, purple mudstone with white light-colored and rhythm with deformation

f: $3975.65 \mathrm{~m}$, purple argillaceous siltstone with bedding inclined plate

g: $4499.3 \mathrm{~m}$, dark purple-red mudstone with mud-gravel

$\mathrm{h}: 4506.6 \mathrm{~m}$, dark-purple, light gray rhythm bedding with calcite particles and bedding deformation

1 , mudstone; 2 ,sandy mudstone; 3 , oil shale; 4 , calcareous clay; 5 , gypsum mudstone; 6 ,saline mudstone; 7 , soft mudstone; 8 , siltstone; 9 , dolomitic siltstone; 10 , fine sandstone; 11 , argillaceous dolomite; 12 , gypsum; 13 , gypsum salt rock; 14 . Salt rock 


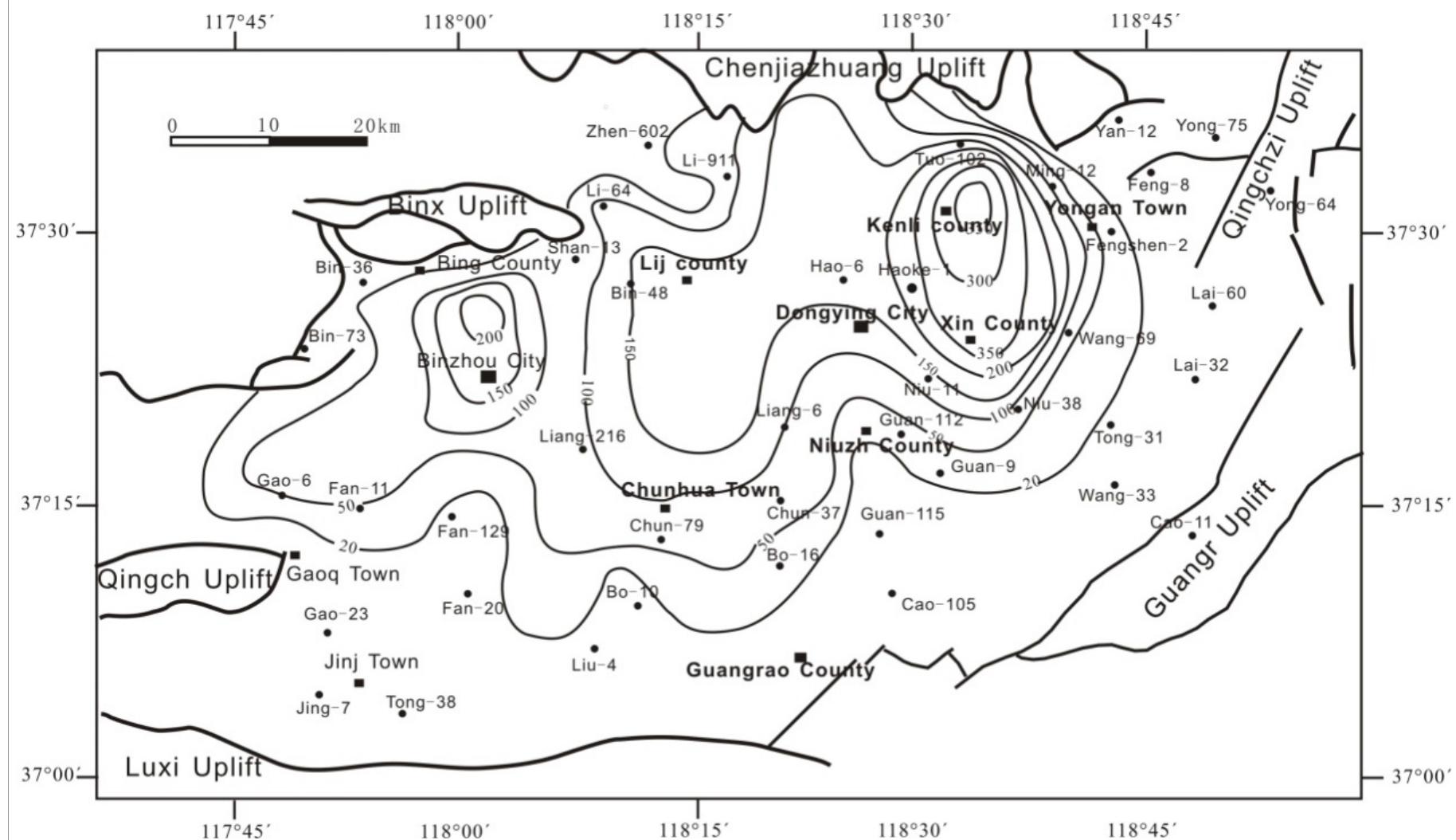

Figure 4: The distribution of total salinity $(\mathrm{g} / \mathrm{L})$ in the lower part of 4th Member of Shahejie Formation from the Paleogene System in Dongying depression.

mudstone of $\mathrm{Es}_{4}$ shows distinct discreteness and fluctuation (Figure 5). The content of most inorganic elements is high in the mudstone but low in adjacent evaporites, except $\mathrm{Na}$ (Table 1). Such distribution is supposed to be associated with the special nature of the dissolution and adsorption of the inorganic element. When organic matter generates hydrocarbon, the organic acids generated can dissolve soluble inorganic salts in evaporites, and dissolved inorganic elements can easily migrate to adjacent mudstones and can accumulate related elements in clayed mudstones. The loss of elements in gypsum-salt for the clayed mudstones has a comparatively large surface area and strong adsorption. The evaporites and mudstone containing many catalytic transitional elements benefit the generation of oil and gas [14-16].

\section{Water type in the evaporate system}

The formation water chemical characteristics are reflection of different sedimentary and diagenetic environment, and ionic substances are the result of water-rock interaction and hydrocarbon accumulation. The ions $\mathrm{Cl}^{-}, \mathrm{SO}_{4}^{2}-, \mathrm{HCO}_{3}^{-}, \mathrm{Na}^{+}, \mathrm{K}^{+}, \mathrm{Ca}^{2+}$ and $\mathrm{Mg}^{2+}$ were known as the main ions in formation water in oil fields. In a closed hydrological system the composition of concentrated lake brines largely depends on labile lithologies that are leached and altered by inflow waters in the drainage basin surrounding a salt lake $[17,18]$. For example, flow across and through limestone aquifers produces inflow waters rich in $\mathrm{Ca}$ and $\mathrm{HCO}_{3}$, dolomite dissolution generates $\mathrm{Mg}$-rich waters, igneous and metamorphic matrices tend to yield silica-rich $\mathrm{Ca}-$ $\mathrm{Na}-\mathrm{HCO}_{3}$ waters, and pyritic shales and other sulfur-rich sediments, such as tuffaceous ashfalls, will contribute inflows rich in sulfate, whereas basic and ultrabasic rocks tend to produce alkaline $\mathrm{Mg}-\mathrm{HCO}_{3}$ waters [19].
Due to the groundwater evaporation, concentration and salt precipitation chloride predominate in the groundwater with main $\mathrm{NaCl}$ salt. The long-term interaction between Water and rock make the greatly cation exchange effect for the absorbed $\mathrm{Ca}^{2+}$ in the rock with $\mathrm{Na}^{+}$ in groundwater, and the exchange reduced the dissolution of the $\mathrm{Na}^{+}$, increase the dissolved $\mathrm{Ca}^{2+}$, resulting in the formation of $\mathrm{CaCl}_{2}$ type water. Generally, $\mathrm{CaCl}_{2}$ type water originates from the deep earth, and reflects a reductive environment with water stagnated and salt highly concentrated. Here, the formation water is dominated by $\mathrm{CaCl}_{2}$, and some water shows $\mathrm{NaHCO}_{3}$. The $\mathrm{Na}_{2} \mathrm{SO}_{4}$ and $\mathrm{MgCl}_{2}$ types of formation water are rare. The development of $\mathrm{CaCl}_{2}$ type water in the evaporites suggested favorable seal development and petroleum preservation.

\section{Carbon isotope response to evaporites}

The value of the carbon isotopes of crude oil $\left(\delta^{13} \mathrm{C}\right)$ mainly depends on organic matter. High $\delta^{13} \mathrm{C}$ is displayed in many hypersaline environments, including some basins in China, such as Qaidam Basin [20], Qianjiang Depression in Jianghan Basin, [21] and Bohai Bay Basin [22]. The heavier carbon isotope is usually associated with the organic matter source mainly dominated by algae and aquatic bacteria $[23,24]$.

High $\delta^{13} \mathrm{C}$ is also shown in the evaporites and mudstones. The $\delta^{13} \mathrm{C}$ of alkanes, aromatics, and non-hydrocarbons is greater than $-27.6 \%$ o, $-25.5 \%$, and $-25.7 \%$, respectively, in the intervals of $3963 \mathrm{~m}$ to $3973 \mathrm{~m}$ and $4024 \mathrm{~m}$ to $4501 \mathrm{~m}$ of the Fs2 Well in the Dongying Depression (Table 2 and Figure 6). At the same time, the fractionation of $\delta^{13} \mathrm{C}$ between different group compositions is relatively small, and the difference is less than $2 \%$ mostly. The highest fractionation occurs between the saturated hydrocarbons and aromatic hydrocarbons, reflecting the characteristics of $\delta^{13} \mathrm{C}$ fractionation in salted lakes [25] 

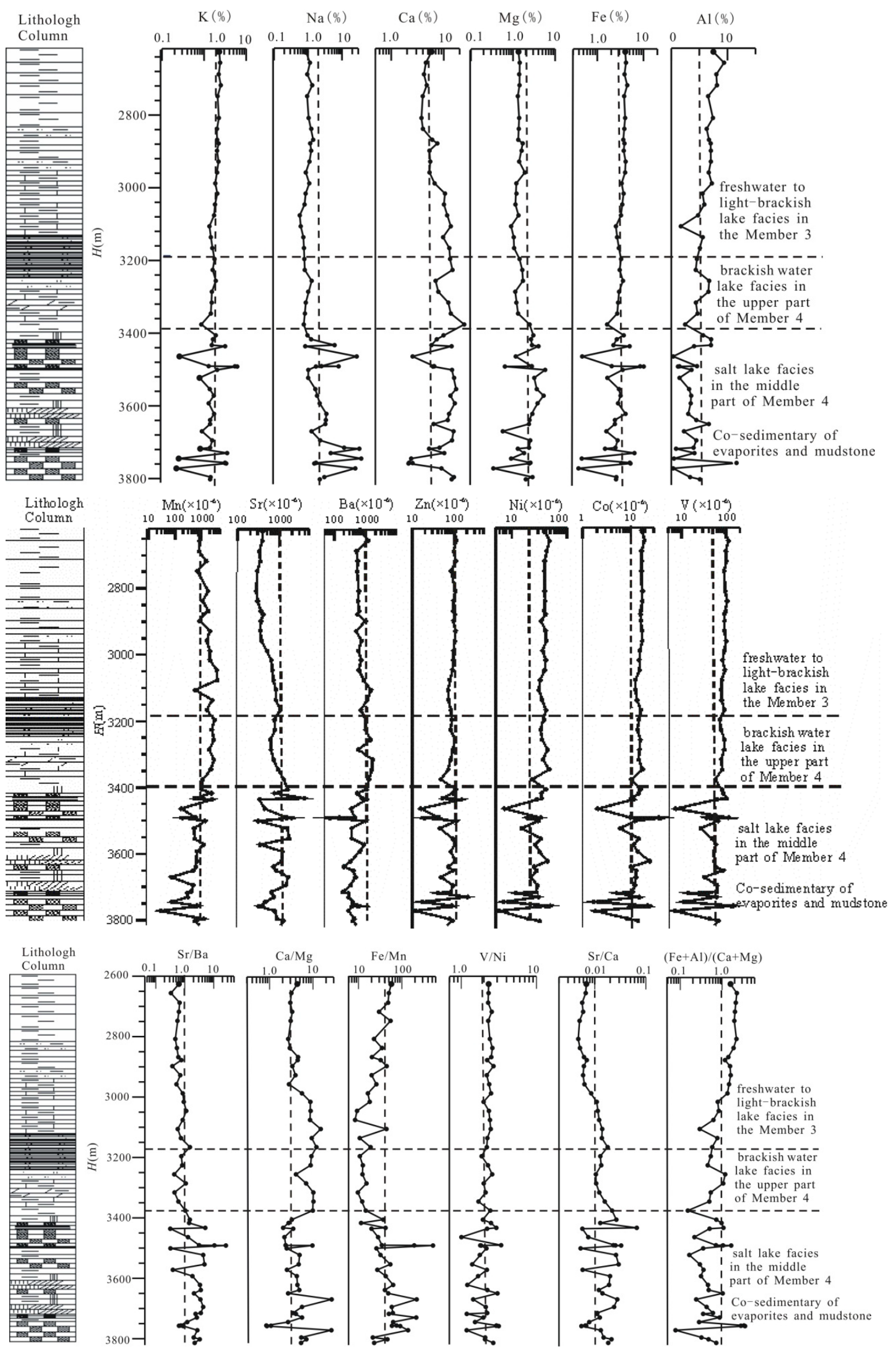

Figure 5: The distribution of the content of mineral elements in the Paleogene system from Hk1 Well in Dongying depression.(a, major minerals; b, trace minerals; $c$ element ratio). 
Citation: Chen ZH, Zhang JQ, Wang L, Zha M (2013) Geochemistry of Evaporites in Lacustrine Basin, Dongying Depression, Bohai Bay Basin, China J Pet Environ Biotechnol 4: 156. doi:10.4172/2157-7463.1000156

Page 7 of 15

\begin{tabular}{|c|c|c|c|c|c|c|c|c|c|c|c|c|c|c|c|c|c|c|}
\hline $\begin{array}{c}\text { Depth } \\
(\mathrm{m})\end{array}$ & Lithology & $\begin{array}{l}\mathrm{Na} \\
(\%)\end{array}$ & $\begin{array}{c}\mathrm{K} \\
(\%)\end{array}$ & $\begin{array}{l}\mathrm{Ca} \\
(\%)\end{array}$ & $\begin{array}{l}\mathrm{Mg} \\
(\%)\end{array}$ & $\begin{array}{l}\mathrm{Fe} \\
(\%)\end{array}$ & $\begin{array}{c}\mathrm{Al} \\
(\%)\end{array}$ & $\begin{array}{c}\mathrm{Mn} \\
\left(10^{-6}\right)\end{array}$ & $\begin{array}{c}\mathrm{Ni} \\
\left(10^{-6}\right)\end{array}$ & $\begin{array}{c}\mathrm{Zn} \\
\left(10^{-6}\right)\end{array}$ & $\begin{array}{c}\mathrm{Sr} \\
\left(10^{-6}\right)\end{array}$ & $\begin{array}{l}\text { Co } \\
\left(10^{-6}\right)\end{array}$ & $\begin{array}{c}\mathrm{Ba} \\
\left(10^{-6}\right)\end{array}$ & $\begin{array}{c}V \\
\left(10^{-6}\right)\end{array}$ & $\mathrm{Sr} / \mathrm{Ba}$ & $\mathrm{Ca} / \mathrm{Mg}$ & $\mathrm{V} / \mathrm{Ni}$ & $\mathrm{Fe} / \mathrm{Mn}$ \\
\hline 3650 & Gray mudstone & 3.23 & 1.39 & 6.38 & 2.38 & 2.4 & 6.67 & 495.38 & 28.37 & 92.75 & 829.9 & 12.91 & 398.2 & 86.04 & 2.08 & 2.68 & 3.03 & 48.45 \\
\hline 3659 & $\begin{array}{l}\text { Dark-gray } \\
\text { mudstone }\end{array}$ & 2.27 & 1.56 & 14.32 & 2.56 & 2.75 & 4.45 & 470.54 & 29.32 & 92.64 & 1399.7 & 12.14 & 324.1 & 62 & 4.32 & 5.59 & 2.11 & 58.44 \\
\hline 3715 & Gypsum-salt & 11.52 & 1.39 & 8.27 & 2.4 & 2.47 & 3.96 & 399.93 & 27.82 & 81.5 & 657.7 & 10.96 & 184.4 & 64.59 & 3.57 & 3.45 & 2.32 & 61.76 \\
\hline 3718 & Gypsum-salt & 32.26 & 0.81 & 5.25 & 1.3 & 1.47 & 0.84 & 293.49 & 11.85 & 41.45 & 652.6 & 5.05 & 277.3 & 14.02 & 2.35 & 4.04 & 1.18 & 50.09 \\
\hline 3730 & Gray mudstone & 4.65 & 3.53 & 10.21 & 1.83 & 6.37 & 4.11 & 298.16 & 30.45 & 204.7 & 735.3 & 14.94 & 281.5 & 59.88 & 2.61 & 5.58 & 1.97 & 213.6 \\
\hline 3745 & Gypsum-salt & 36.72 & 0.25 & 0.24 & 0.9 & 0.46 & 0.47 & 73.25 & 7.14 & 16.89 & 458.0 & 1.69 & 377.4 & 10.89 & 1.21 & 0.27 & 1.53 & 62.80 \\
\hline 3772 & Gypsum-salt & 24.61 & 0.22 & 9.02 & 0.34 & 0.39 & 0.33 & 28.2 & 5.88 & 11.76 & 770.2 & 1.84 & 283.9 & 6.93 & 2.71 & 26.5 & 1.18 & 138.3 \\
\hline 3802 & $\begin{array}{l}\text { Purple-red } \\
\text { mudstone }\end{array}$ & 2.22 & 1.39 & 14.11 & 2.01 & 2.54 & 5.08 & 547.92 & 32.09 & 89.59 & 1247.7 & 14.1 & 379.5 & 66.32 & 3.29 & 7.02 & 2.07 & 46.36 \\
\hline 3856 & $\begin{array}{l}\text { Purple-red } \\
\text { mudstone }\end{array}$ & 3.65 & 2.01 & 3.92 & 2.42 & 1 & 6.8 & 403.09 & 34.79 & 117.8 & 801.8 & 13.45 & 816.4 & 100 & 0.98 & 1.62 & 2.87 & 24.81 \\
\hline 3862 & Gypsum-salt & 27.08 & 0.28 & 3.4 & 0.58 & 0.46 & 0.53 & 68.91 & 7.09 & 16.63 & 351.5 & 1.94 & 254.4 & 8.91 & 1.38 & 5.86 & 1.26 & 66.75 \\
\hline 3884 & Gypsum-salt & 34.98 & 0.2 & 3.17 & 0.29 & 0.33 & 0.42 & 28.3 & 4.67 & 11.25 & 368.8 & 2.45 & 262.4 & 7.23 & 1.41 & 10.9 & 1.55 & 116.6 \\
\hline 3896 & Purple & 5.21 & 1.79 & 4.33 & 1.87 & 3.09 & 3.59 & 422.06 & 31.69 & 107.5 & 1429.4 & 12.81 & 583.0 & 90 & 2.45 & 2.32 & 2.84 & 73.21 \\
\hline 3902 & Purple & 3.76 & 1.75 & 10.82 & 2.54 & 3.02 & 5.35 & 354.54 & 28.92 & 96.73 & 825.4 & 13.89 & 487.8 & 68.95 & 1.69 & 4.26 & 2.38 & 85.18 \\
\hline 3914 & Purple & 3.95 & 1.44 & 8.67 & 1.98 & 2.66 & 5.65 & 643.14 & 25.95 & 97.61 & 618.7 & 12.93 & 262.6 & 60.7 & 2.36 & 4.38 & 2.34 & 41.36 \\
\hline
\end{tabular}

Table 1: The distribution of mineral elements and some ration parameters in the co-sedimentary system of saline and mud in the middle part of Es from the well Hk1 in Dongying depression.

\begin{tabular}{|c|c|c|c|c|}
\hline \multirow{2}{*}{ Depth(km) } & \multirow{2}{*}{ Lithology } & \multicolumn{3}{|c|}{ Values of $\delta^{13} \mathrm{C}(\%)$} \\
\hline & & alkane & aromatic hydrocarbon & non-hydrocarbon \\
\hline 3.963 & Dark-gray salted mudstone & -27.6 & -25.5 & -25.7 \\
\hline 3.968 & Dark-gray salted mudstone & -27.3 & -25.3 & -25.6 \\
\hline 3.971 & Dark-gray salted mudstone & -27.4 & -25.3 & -25.5 \\
\hline 3.973 & Dark-gray salted mudstone & -27.4 & -25.3 & -25.6 \\
\hline 4.024 & Salted rock & -25.0 & -23.9 & -24.5 \\
\hline 4.295 & Laminated mudstone & -24.2 & -22.8 & -24.3 \\
\hline 4.301 & Laminated mudstone & -21.0 & -21.0 & -22.6 \\
\hline 4.498 & Dark-gray gypsum-salted mudstone & -22.4 & -23.6 & -23.6 \\
\hline 4.499 & Dark-gray gypsum-salted mudstone & -25.2 & -24.3 & -25.3 \\
\hline 4.500 & Dark-gray gypsum-salted mudstone & -22.1 & -23.2 & -24.2 \\
\hline 4.501 & Dark-gray gypsum-salted mudstone & -23.9 & -24.3 & -25.6 \\
\hline
\end{tabular}

Table 2: The characteristics of carbon isotope of the group composition of the organic matter in the middle part of Member-4 of Shahejie Formation from the Well Fs2 in the Dongying depression.

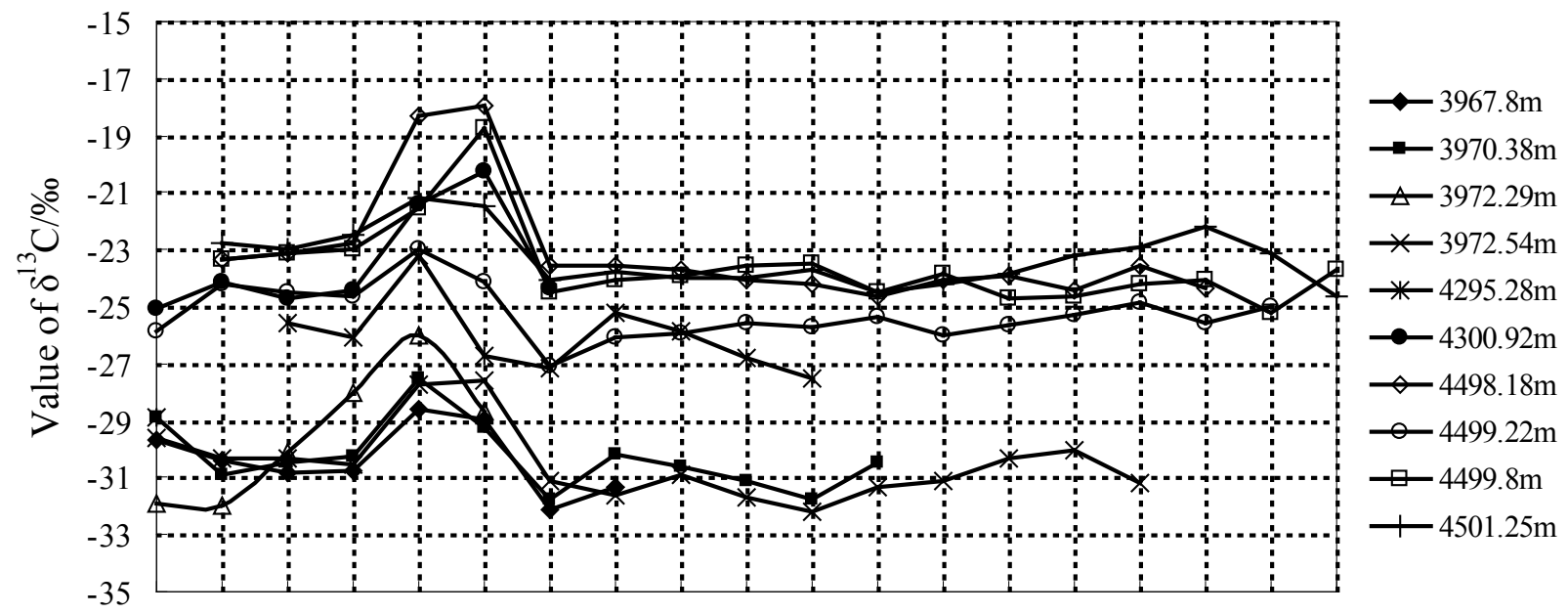

$\begin{array}{lllllllllllllllllll}13 & 14 & 15 & 16 & 17 & 18 & 19 & 20 & 21 & 22 & 23 & 24 & 25 & 26 & 27 & 28 & 29 & 30 & 31\end{array}$

Carbon number of n-alkanes

Figure 6: The characteristics of carbon isotope of $n$-alkanes from the source rocks of the middle part of Member-4 of Shahejie Formation from the Well Fs2 in Dongying depression. 
The $\delta^{13} \mathrm{C}$ of the $\mathrm{n}$-alkane series only slightly varies, except a remarkably high $\delta^{13} \mathrm{C}$ of $\mathrm{C}_{17}$ and $\mathrm{C}_{18}$. The $\delta^{13} \mathrm{C}$ of n-alkanes increase slightly with increasing carbon number, reflecting a characteristic of the $\delta^{13} \mathrm{C}$ from mature alkanes in hypersaline lacustrines.

Comparatively, the values of $\delta^{13} \mathrm{C}$ in the interval $3963 \mathrm{~m}$ to $3973 \mathrm{~m}$ are low, around $-27.5 \%$, $-25.5 \%$, and $-25.5 \%$ or for alkane hydrocarbon, aromatic hydrocarbon, and non-hydrocarbon, respectively. By contrast, the values of $\delta^{13} \mathrm{C}$ in the interval $4024 \mathrm{~m}$ to $4501 \mathrm{~m}$ are higher, distributed in the ranges $-25 \%$ to $-21 \%$, $-24.3 \%$ to $-21 \%$, and $-25.6 \%$ to $-22.6 \%$, respectively. These values reflect the effect of thermal evolution on the distribution of $\delta^{13} \mathrm{C}$ in similar sedimentary environments. The measured vitrinite reflectance $\left(R_{\mathrm{o}}\right)$ is $0.95 \%$ at a depth of $3972 \mathrm{~m}$, whereas at $4500 \mathrm{~m}, R$ reaches $1.2 \%$, indicating much higher thermal maturation.

The stability of various carbon bonds varies: ${ }^{13} \mathrm{C}-{ }^{13} \mathrm{C}>{ }^{13} \mathrm{C}-{ }^{12} \mathrm{C}>$ ${ }^{12} \mathrm{C}-{ }^{12} \mathrm{C}$. The generated hydrocarbon has lighter isotopic composition than its parent material because the ${ }^{12} \mathrm{C}-{ }^{12} \mathrm{C}$ bond is easier to break, resulting in a heavier isotope $\left(\delta^{13} \mathrm{C}\right)$ gathered in residual organic matter. This result explains the heavier carbon isotope distribution in the interval $4024 \mathrm{~m}$ to $4501 \mathrm{~m}$.

The distribution of $\delta^{13} \mathrm{C}$ was not only controlled by maturity but also resulted from the reaction Thermochemical Sulfate Reduction (TSR). TSR is a function of the interaction between sulfate and hydrocarbons, and in the process, sulfate minerals are deoxidized into acid gases, such as $\mathrm{H}_{2} \mathrm{~S}$. In carbonate rocks, the TSR reaction is the widespread occurrence of geological phenomena and has been reported in some China basins [26,27]. A certain thickness of anhydrite, adequate hydrocarbons, and higher paleothermal energy are the prerequisites for TSR reaction. TSR reaction is a very complex chemical reaction that significantly changes carbon isotopes and enriches $\mathrm{H}_{2} \mathrm{~S}$ [28].

In TSR reaction with the consumption of hydrocarbon, the ${ }^{12} \mathrm{C}-{ }^{12} \mathrm{C}$ bond is broken with priority, and more ${ }^{12} \mathrm{C}$ is involved in the reaction. More ${ }^{13} \mathrm{C}$ is retained in the residual hydrocarbons; thus, residual hydrocarbon after the reaction is relatively enriched in ${ }^{13} \mathrm{C}$, and the gained weight of $\delta^{13} \mathrm{C}$ can reach $2 \%$ o to $4 \%$ in the Sichuan basin [26]. In the interval $4024 \mathrm{~m}$ to $4501 \mathrm{~m}$ of the Fs2 Well in Dongying Depression, conditions exist for TSR reaction with higher content of sulfate and high temperature. As the differentiation of the $\delta^{13} \mathrm{C}$ value in the two intervals ( $3963 \mathrm{~m}$ to $3973 \mathrm{~m}$ and $4024 \mathrm{~m}$ to $4501 \mathrm{~m}$ ) reaches more than $5 \%$, the TSR reaction contributes to $\delta^{13} \mathrm{C}$ distribution.

\section{Biomarker response in evaporite system}

Source-related biomarker parameters: The mature to highly mature hydrocarbon source rocks in the evaporite system tend to have a predominance of even carbon numbers, showing the "single-peak" distribution of n-alkanes (Figure 7). The peak carbon is located between $\mathrm{nC}_{16}$ and $\mathrm{nC}_{20}$, and most of the peak carbons are $\mathrm{nC}_{16}$ and $\mathrm{nC}_{18}$. The distribution of $\mathrm{Pr} / \mathrm{Ph}$ is well differentiated by the two class of samples, and the obvious advantage of phytane $(\mathrm{Pr} / \mathrm{Ph}<1.0)$ is demonstrated in the evaporite samples from $\mathrm{Es}_{4}$ (Figure 8). Haven et al. [29] found that low $\mathrm{Pr} / \mathrm{Ph}(<1)$ is typical of hypersaline environments, where the ratio appears to be controlled by the effects of variable salinity on halophilic bacteria [29]. Likewise, Schwark et al. [30] noted a general decrease in $\mathrm{Pr} / \mathrm{Ph}$ during the deposition of the Permian Kupferschiefer sequence in Germany and interpreted it to indicate increasing paleosalinity [30]. Although the utility of $\mathrm{Pr} / \mathrm{Ph}$ to accurately describe the redox state of paleoenvironments is limited by several factors, including variable source inputs, different rates of early generation, variations at higher maturity, and analytical uncertainty [31], the supporting relationship

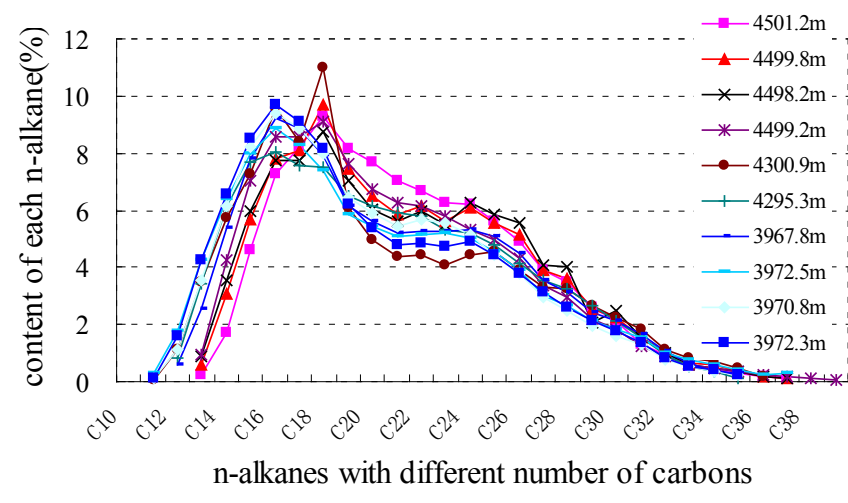

Figure 7: The distribution of n-alkanes from high-matured source rocks deposited in the evaporated system of the Well Fs2 in Dongying depression.

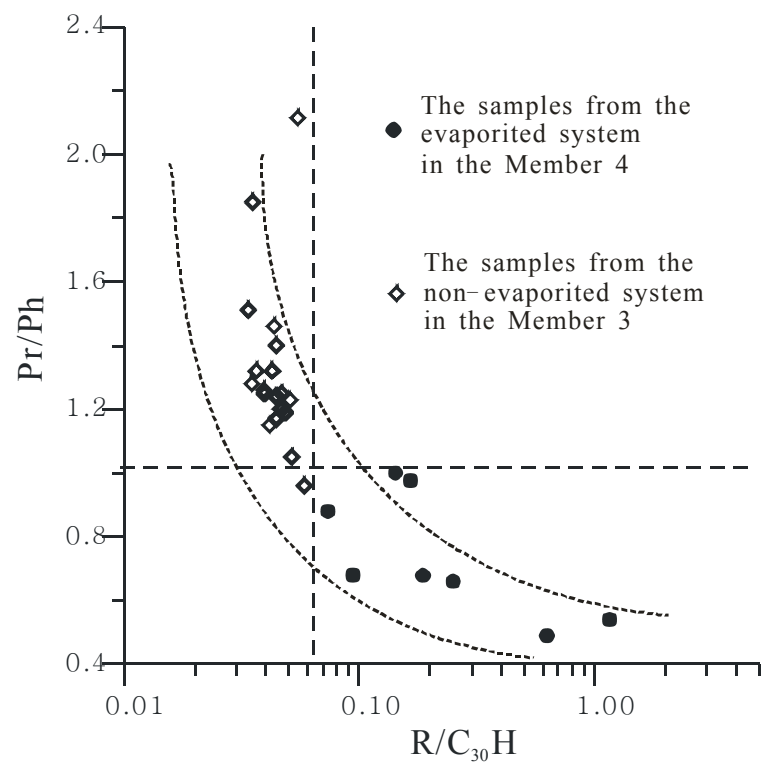

Figure 8: The distribution of $\mathrm{Pr} / \mathrm{Ph}$ and $\mathrm{y} / \mathrm{C}_{30} \mathrm{H}$ from the source rocks in the evaporated system of $E_{s 4}$ and non-evaporated system of $E_{s 3}$ in Dongying depression.

between $\mathrm{Pr} / \mathrm{Ph}$ and the gammacerane index confirms the inferred salinity relationship.

In the series of tricyclic terpanes, gamma content is remarkably high, indicative of marked stratification in a salted water environment with halocline $[32,33]$, because gammacerane indicates a stratified water column in marine and non-marine source-rock depositional environments [6], commonly resulting from hypersalinity at depth (Figure 9). The value 0.065 of $\gamma / \mathrm{C}_{30} \mathrm{H}$ is a division for source rocks between the evaporite system and non-evaporite system. For the evaporite system, the value of $\gamma / \mathrm{C}_{30} \mathrm{H}$ is generally higher than 0.065 , but not for the non-evaporite system. This result indicates that increased water salinity during the deposition of source rocks increases gammacerane indices and reduces pristine/phytane, corresponding to the result of the investigation of the biomarkers of oils from lacustrine source rocks in Angola [32]. In the distribution of hopane series with a long chain, the characteristics of $\mathrm{C}_{35}$ hopane $>\mathrm{C}_{34}$ hopane $>\mathrm{C}_{33}$ hopane are shown, and the baseline shifts (Figure 9), fully reflecting the characteristics of biomarkers in a depositional environment with high salinity [5, 34-36]. At the same time, the differentiation of biomarker 


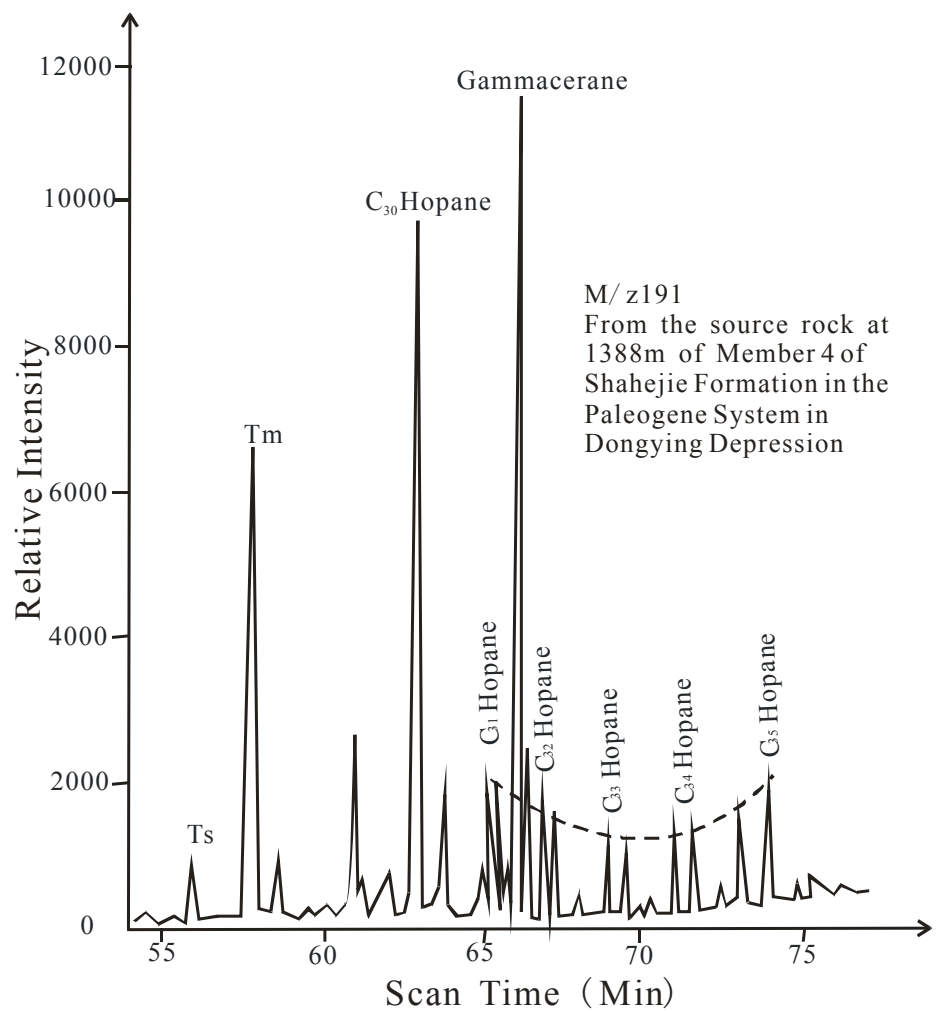

Figure 9: The distribution of a typical response of gammacerane and the hopanes series in the $\mathrm{m} / \mathrm{z} 191$ in the evaporated system in Dongying depression.
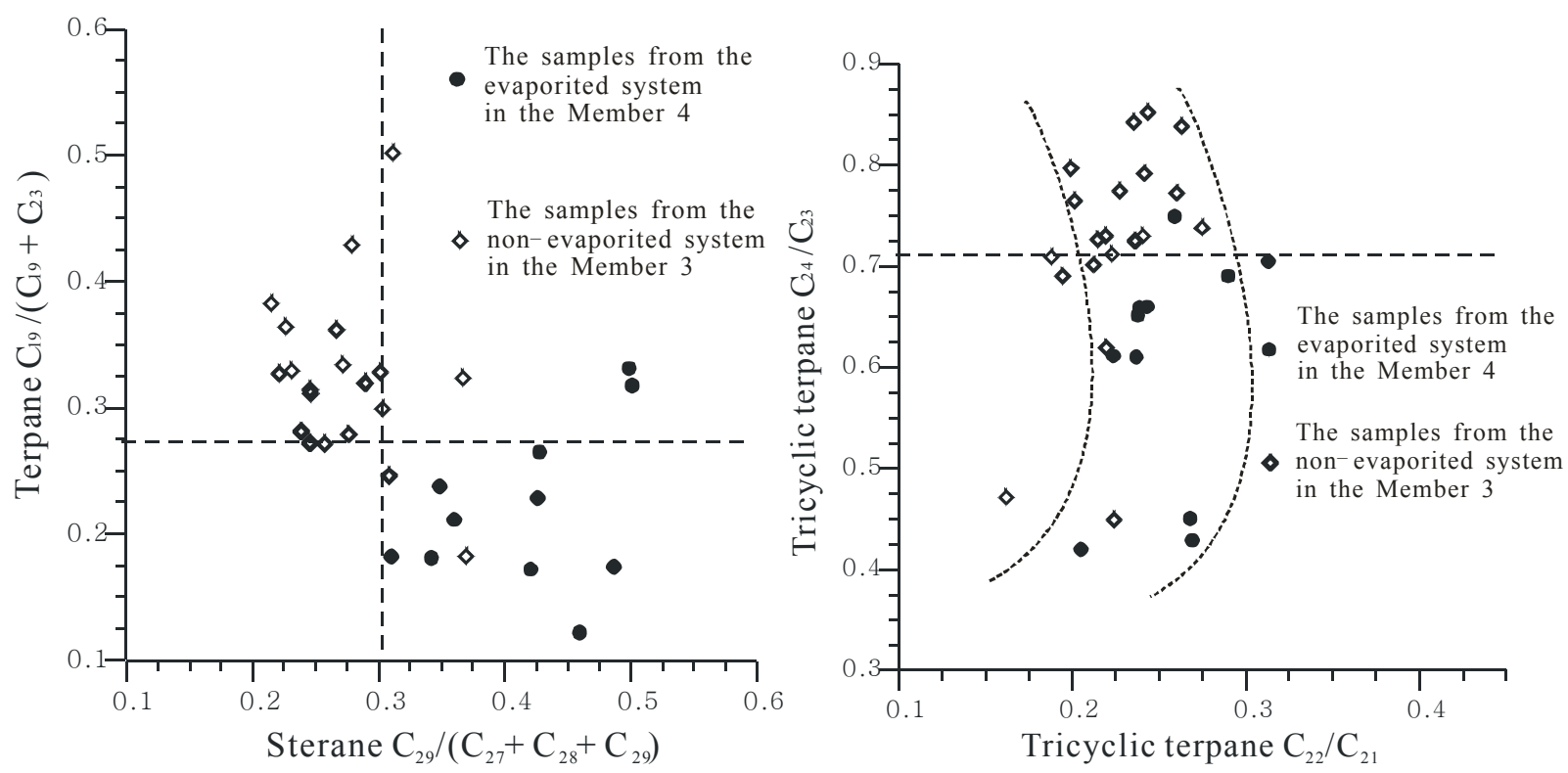

Figure 10: The distribution of $\mathrm{C}_{19} /\left(\mathrm{C}_{19}+\mathrm{C}_{23}\right)$ from terpanes and $\mathrm{C}_{29} /\left(\mathrm{C}_{27}+\mathrm{C}_{28}+\mathrm{C}_{29}\right)$ from steranes $(\mathrm{a})$ and the distribution of $\mathrm{C}_{24} / \mathrm{C}_{23}$ and $\mathrm{C}_{22} / \mathrm{C}_{21}$ from tricyclic terpanes $(\mathrm{b})$ in the different sedimentary systems in Dongying depression.

responses for different source rocks in the evaporite system of $\mathrm{Es}_{4}$ and the non-evaporite system of $\mathrm{Es}_{3}$ in the Dongying Depression is exhibited by other indicators, such as $\mathrm{C}_{19} /\left(\mathrm{C}_{19}+\mathrm{C}_{23}\right)$ from terpanes, $\mathrm{C}_{29} /$ $\left(\mathrm{C}_{27}+\mathrm{C}_{28}+\mathrm{C}_{29}\right)$ from steranes, and $\mathrm{C}_{24} / \mathrm{C}_{23}$ and $\mathrm{C}_{22} / \mathrm{C}_{21}$ from tricyclic terpanes (Figure 10). The divided values of indicators $\mathrm{C}_{24} / \mathrm{C}_{23}, \mathrm{C}_{19} /$ $\left(\mathrm{C}_{19}+\mathrm{C}_{23}\right)$, and $\mathrm{C}_{29} /\left(\mathrm{C}_{27}+\mathrm{C}_{28}+\mathrm{C}_{29}\right)$ are $0.70,0.27$, and 0.30 , respectively.
For the source rocks from the evaporite system, the values of $\mathrm{C}_{24} / \mathrm{C}_{23}$ and $\mathrm{C}_{19} /\left(\mathrm{C}_{19}+\mathrm{C}_{23}\right)$ are generally lower than 0.70 and 0.27 , respectively, whereas the values of $\mathrm{C}_{29} /\left(\mathrm{C}_{27}+\mathrm{C}_{28}+\mathrm{C}_{29}\right)$ are generally higher than 0.30 .

Biomarker maturity parameters: An analysis of many samples of the profile of the Paleogene System in the Dongying Depression reveals a distinct response of typical maturity-related biomarker parameters in 
the evaporite system compared with that in the non-evaporite system. The values of $\mathrm{C}_{29} \beta \beta /(\beta \beta+\alpha \alpha), \mathrm{C}_{29} 20 \mathrm{~S} /(20 \mathrm{~S}+20 \mathrm{R})$, and $\mathrm{Ts} /(\mathrm{Ts}+\mathrm{Tm})$ began negative reversion at a depth of around $3.5 \mathrm{~km}$ to $3.6 \mathrm{~km}$ in the trend of their evolution, consistent with the sharp increase of the carbonate content in the interval (Figures 11 and 12).

Regional geological data show that at a shallower burial depth $(<3.57 \mathrm{~km})$, the main source rocks are calcareous shale and clayed mudstone and that at a great burial depth $(>3.57 \mathrm{~km})$, the gypsum and salt rock content increases significantly and the evaporite and mudstone form a co-sedimentary system. Take the Hk1 Well as an example. Below $3.57 \mathrm{~km}$, gypsum and salt rock developed, and in the symbiotic system of evaporite and mudstone, the content of elements, such as calcium and sodium, increased significantly than that in the upper layer; the ratios of $\mathrm{Sr} / \mathrm{Ba}, \mathrm{Sr} / \mathrm{Ca}$, and $\mathrm{Fe} / \mathrm{Mn}$ showed a significant high-value response, indicating a typical high-salt environment [36]. In such a high-salt environment, the negative reversion of $C_{29} \beta \beta /(\beta \beta+\alpha \alpha)$, $\mathrm{C}_{29} 20 \mathrm{~S} /(20 \mathrm{~S}+20 \mathrm{R})$, and $\mathrm{Ts} /(\mathrm{Ts}+\mathrm{Tm})$ showed good relations with high levels of gypsum-salt, reflecting the effect of inhibition or retardation on thermal evolution by gypsum-salt minerals.

The retarding effect of carbonate minerals in the transforming process from organic matter to oil and gas is an important reason for the delay and backwardness of oil and gas generation in the source rocks of evaporite systems, and such retarding effect is mainly controlled by the absence of the catalysis of clay minerals [37]. The related thermal simulation experiment also showed that carbonate rocks have an anti-catalytic effect on hydrocarbon generation from kerogen and that increasing temperature significantly increases the anti-catalytic function [38]. Clay minerals in shale catalyze the transformation of kerogen, whereas calcites in gypsum-salt rock have a small or no role in the transformation of kerogen. In addition, organic matter in gypsum-salt rock is mainly found within cryptocrystalline or fine-grained carbonate minerals and is not easily released and thus may retard thermal evolution in evaporite systems [39].

Retardation was demonstrated by many immature to low-maturity

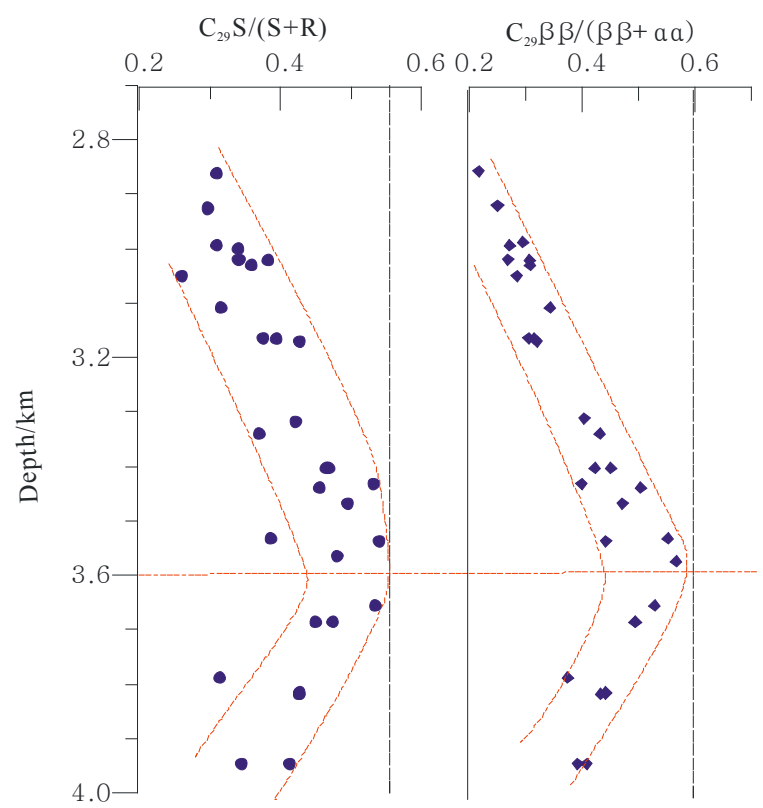

Figure 11: The distribution of the parameters of $C_{29} \beta \beta /(\beta \beta+\alpha \alpha)$ and $C_{29} S /$ $(S+R)$ in profile from $E_{s 4}$ in Dongying depression.

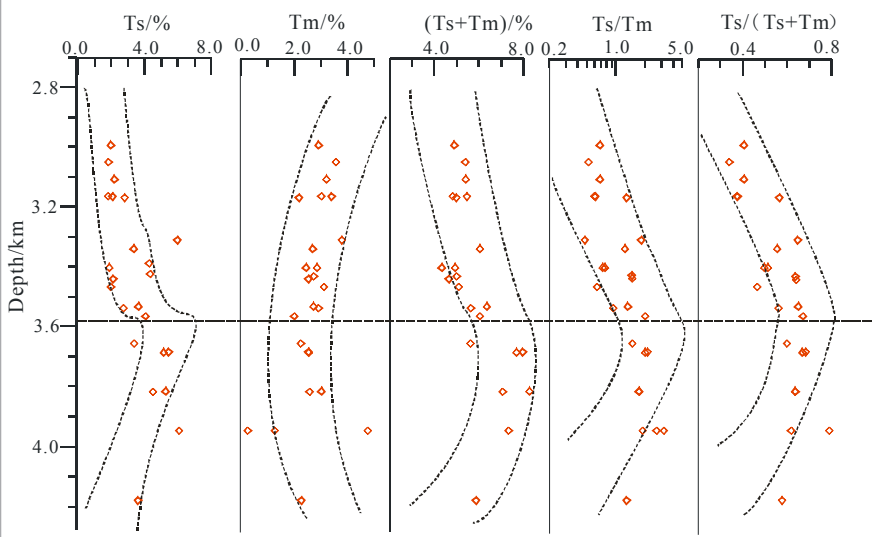

Figure 12: The distribution of the parameters of $\mathrm{Ts} / \mathrm{Tm}, \mathrm{Ts} /(\mathrm{Ts}+\mathrm{Tm})$ in profile from $E_{s 4}$ in Dongying depression.

oils discovered in several co-sedimentary systems of evaporite and mudstone. Examples include source rocks from the Lower Cretaceous in the South Florida Basin, the Guang-33 Well in the Jianghan Basin, the Yuecan-1 and Kaiqian-67 Wells in the Qaidamu Basin, and the Bamianhe area in the Dongying Depression. For instance, in the Biyang Depression in China, the threshold depth of oil generation from the dolomites was $300 \mathrm{~m}$ deeper than that from the mudstone in the Paleogene system, and the maturity indicated by biomarkers was significantly negatively correlated to the carbonate content in rocks.

Thermal retardation in the evaporite system is not only reflected by biomarker parameters but also displayed in the distribution of conventional thermal indicators, including vitrinite reflectance $\left(R_{\mathrm{o}}\right)$ and pyrolysis peak temperature $\left(T_{\max }\right)$. The negative departure of $R_{0}$ and $T_{\max }$ in the overpressured interval (high overpressure, the pressure coefficient reaches 1.8) from $2400 \mathrm{~m}$ to $3400 \mathrm{~m}$ suggests the inhibition of thermal evolution in response to overpressure [36]. The greater decline of $R_{\mathrm{o}}$ and $T_{\max }$ in the hypersaline interval from $3400 \mathrm{~m}$ to 4000 $\mathrm{m}$ indicates similar retardation because of the presence of carbonate minerals, as with related biomarker maturity ratios [36].

\section{Hydrocarbon Generation and Expulsion from Evaporites}

\section{Group composition and organic matter type}

The capacity of hydrocarbon generation and expulsion from the cosedimentary system of evaporites and mudstone (salted lake phase) is of widespread concern. Organic matter and high-quality source rocks are enriched in the depositional sequence of carbonate, sulfate, and chloride salt in salted lakes. In different sequences, the composition of organic matter and thermal evolution show a certain difference.

Evaporites in $\mathrm{Es}_{4}$ in the Dongying Depression are mainly composed of anhydrite and salt rock, and their paleosalinity is about $12 \%$ to $26 \%$ [40]. The high-salt environment may limit the growth of parasites and may be conducive to the formation of algal blooms and may thus increase the productivity of organic matter $[13,41]$. Moreover, the heatconductive property of gypsum-salt is much higher than that of sand and shale; thus, source rocks in thick layers of gypsum rock can obtain heat earlier [9]. This early heating facilitates hydrocarbon generation.

To investigate the ability to generate and expel hydrocarbons from this co-sedimentary of evaporites and mudstone, a series of indicators was investigated from the Fs2 Well. The basic composition of the 
organic matter is sapropel (the dominant component) and vitrinite (Table 3).

The sapropel and vitrinite content is $78 \%$ to $92 \%$ and $8.3 \%$ to $22.3 \%$, respectively, and few exinite and inertinite exist. The index of the organic matter type is $58.9 \%$ to $85.4 \%$, representing types I and II of kerogen. The group composition of the organic matter is mainly alkane (content: $74.49 \%$ to $80.98 \%$ ) and aromatics and non-hydrocarbons in lower proportion (aromatics: $3.13 \%$ to $11.36 \%$; non-hydrocarbons: $4.71 \%$ to $15.25 \%)$. The maturity parameters of vitrinite reflectance $\left(R_{\mathrm{o}}\right)$ and pyrolysis peak temperature $\left(T_{\max }\right)$ are greater than $0.93 \%$ and $400^{\circ} \mathrm{C}$, respectively, indicating that the samples have passed the peak period of oil generation. However, the distribution of maturity parameters in the co-sedimentary system shows an irregular linear increase with burial depth. The increased thermal conductivity of the evaporites reduces the maturity parameters in the evaporites compared with those in the mudstone. For instance, $R_{\mathrm{o}}$ and $T_{\max }$ pyrolysis in the mudstone at $4300.92 \mathrm{~m}$ are $1.17 \%$ and $419^{\circ} \mathrm{C}$, respectively, whereas in the gypsum-salted mudstone at $4498.8 \mathrm{~m}$ to $4499.8 \mathrm{~m}$, the three samples of $R_{\mathrm{o}}$ are distributed from $1.13 \%$ to $1.14 \%$, and the $T_{\max }$ of two samples are 403 and $417^{\circ} \mathrm{C}$, respectively.

\section{Capacity for hydrocarbon generation and expulsion}

A calculation model of hydrocarbon generation and expulsion was built based on geochemical information from pyrolysis [10]. A series of indicators was calculated to study the capacity for hydrocarbon generation and expulsion from the co-sedimentary system in the two intervals of the Fs1 Well.

Results show the stronger capacity of hydrocarbon generation and expulsion in the interval $3966 \mathrm{~m}$ to $3975 \mathrm{~m}$ (Figure 13): residual organic carbon content $\left(C_{\mathrm{t}}\right)$ ranged from $0.6 \%$ to $2.63 \%$ with an average of $1.54 \%$; original organic carbon content $\left(C_{\mathrm{o}}\right)$ was distributed in the range $1.8 \%$ to $4.1 \%$; the content of residual soluble hydrocarbons $\left(S_{1}\right)$ and pyrolysis hydrocarbons $\left(S_{2}\right)$ is distributed in the ranges $0.85 \mathrm{mg} / \mathrm{g}$ to $8.24 \mathrm{mg} / \mathrm{g}$ and $0.48 \mathrm{mg} / \mathrm{g}$ to $5.69 \mathrm{mg} / \mathrm{g}$, averaging 4.31 and $2.83 \mathrm{mg} / \mathrm{g}$, respectively; the remaining hydrocarbon generation potential $\left(S_{1}+S_{2}\right)$ is distributed from $1.33 \mathrm{mg} / \mathrm{g}$ to $13.54 \mathrm{mg} / \mathrm{g}$ with an average of $7.14 \mathrm{mg} / \mathrm{g}$; the soluble hydrocarbon index $\left(H I\right.$, equivalent to $\left.S_{1} \times 100 / C_{\mathrm{t}}\right)$ is distributed in the range $142 \mathrm{mg} / \mathrm{g}$ to $320 \mathrm{mg} / \mathrm{g}$ with an average of $255 \mathrm{mg} / \mathrm{g}$, indicating that the organic matter entered the peak period of hydrocarbon generation. The conversion rate of pyrolysis $\left(K_{\mathrm{t}}\right.$, equivalent to $S_{1} \times 100 /$ $\left(S_{1}+S_{2}\right)$ is high, generally greater than $55 \%$, whereas the hydrogen index ( $I H$, equivalent to $S_{2} \times 100 / C_{\mathrm{t}}$ ) is significantly low (less than $200 \mathrm{mg} / \mathrm{g}$ ). The original hydrocarbon generating potential $\left(S_{\mathrm{o}}\right)$ and the amount of hydrocarbon expelled $\left(S_{\mathrm{p}}\right)$ are distributed in $10 \mathrm{mg} / \mathrm{g}$ to $40 \mathrm{mg} / \mathrm{g}$ and 10 $\mathrm{mg} / \mathrm{g}$ to $20 \mathrm{mg} / \mathrm{g}$, respectively. The efficiency of hydrocarbon expulsion $\left(K_{\mathrm{p}}\right.$, equal to $\left.S_{\mathrm{o}} \times 100 / S_{\mathrm{p}}\right)$ is higher than $60 \%$ generally, indicating that the source rocks in the co-sedimentary system can generate and expel hydrocarbon.

In the $4498 \mathrm{~m}$ to $4504 \mathrm{~m}$ interval, source rocks enter the highmaturity stage, and the indicators are quite different, showing that the high thermal maturity reduced the residual capacity for hydrocarbon generation and expulsion: $H I$ is no higher than $150 \mathrm{mg} / \mathrm{g}$, and the $H I$ of most of the samples is lower than $50 \mathrm{mg} / \mathrm{g}$; $I H$ is less than $50 \mathrm{mg} / \mathrm{g}$; $K_{\mathrm{t}}$ is over $60 \%$ mostly; and $K_{\mathrm{p}}$ is more than $90 \%$, whereas some samples even reach $95 \% . S_{1}$ and $S_{2}$ are lower than 1.0 and $0.5 \mathrm{mg} / \mathrm{g}$, respectively; $S_{1}+S_{2}$ is no greater than $1.5 \mathrm{mg} / \mathrm{g}$. The original potential of hydrocarbon generation and expulsion is also limited, lower than $15 \mathrm{mg} / \mathrm{g}$, and that of most of the samples is below $6 \mathrm{mg} / \mathrm{g}$.

\section{Discussion: Significance of the Evaporite}

\section{The formation of evaporites}

Regarding the formation of the evaporites here, Chen et al. [42] and Jian-hui et al.[43] suggested that evaporites form in a shallow lake, whereas mudstones form in a deep lake [42,43]. Laiyi et al. [44] considered that co-sediment is formed in alternating sedimentary environments from salified water to fresh water [44]. However, the current dominant view is that the co-sediment is formed in deep water, whereas a salted lake background is characterized by "mountains and deep basin" $[45,46]$. This point is based on the fact that the Paleogene Dongying Depression is surrounded by mountains, buried hills, and alluvial fans, which form a comparatively closed sedimentary system.

Salt lake in the western Qaidam basin in China is a typical inland salt lake, in which has formed extensive evaporite, and its formation mechanism can be refered. In the co-sedimentation of the evaporites and source rocks in age of Oligocene and Miocene in the western Qaidam basin, the prospective oil source rocks were just distributed stratigraphically and tectonically in the locations where halite and gypsum were deposited. A genetic model was postulated for evaporites and source rocks, which was described as "big shallow water saline lake surrounding small deep water brine lake" [47]. Jin and Zha [9] believed that water depth controlled both on deposit ion of the evaporites and the accumulation of organic matter in the salt lake environment [47].

\section{The significance of evaporites for the organic matter}

At the beginning of the evaporite formation, due to the salinity increase or the mixture of different salinity water, the bottom water is at stagnation, thus causing the death of various organisms. But because the river continuously supplied biological and organic substances, lakes contained a large number of various biological residue and organic material. When the lake salinity increased, the various creatures will die and drown in the lake, and in consequence humus mud phase at

\begin{tabular}{|c|c|c|c|c|c|c|c|c|c|c|}
\hline \multirow{2}{*}{$\begin{array}{l}\text { Depth } \\
\text { (m) }\end{array}$} & \multirow[b]{2}{*}{ Lithology } & \multicolumn{2}{|c|}{ Maturity parameters } & \multicolumn{2}{|c|}{ Composition (\%) } & \multicolumn{2}{|c|}{ Organic matter type } & \multicolumn{3}{|c|}{ Group (\%) } \\
\hline & & $\begin{array}{l}T_{\max } \\
\left({ }^{\circ} \mathrm{C}\right)\end{array}$ & $\begin{array}{l}\text { Ro } \\
(\%)\end{array}$ & sapropel & vitrinite & $\begin{array}{l}\text { Type } \\
\text { index }\end{array}$ & type & alkanes & aromatics & $\begin{array}{c}\text { Non- } \\
\text { hydrocarbon }\end{array}$ \\
\hline 3967.8 & Salted mudstone & 422 & 0.93 & 78.7 & 21.3 & 62.7 & $\mathrm{II}_{1}$ & 80.53 & 11.32 & 4.74 \\
\hline 3970.7 & Salted mudstone & 418 & 1.00 & 89.7 & 10.3 & 81.9 & 1 & 79.90 & 11.08 & 5.15 \\
\hline 3972.3 & Salted mudstone & 417 & 0.95 & 91.7 & 8.3 & 85.4 & I & 80.11 & 11.36 & 4.83 \\
\hline 3972.5 & Salted mudstone & 419 & 0.98 & 91.3 & 8.7 & 83.8 & 1 & 75.65 & 10.21 & 4.71 \\
\hline 4300.9 & Laminated mudstone & 419 & 1.17 & 85.7 & 14.3 & 74.9 & $\mathrm{II}_{1}$ & - & - & - \\
\hline 4498.2 & Gypsum-salted mudstone & 403 & 1.13 & 90.7 & 9.3 & 83.7 & 1 & 79.26 & 3.13 & 9.09 \\
\hline 4499.2 & Gypsum-salted mudstone & 421 & 1.14 & 87.7 & 12.3 & 78.4 & $\mathrm{II}_{1}$ & 80.98 & 4.35 & 7.61 \\
\hline 4499.8 & Gypsum-salted mudstone & 417 & 1.14 & 78.3 & 20.3 & 61.8 & $\mathrm{II}_{1}$ & 76.53 & 4.50 & 12.54 \\
\hline 4501.2 & Gypsum-salted mudstone & 427 & 1.24 & 82.7 & 15.7 & 69.3 & $\mathrm{II}_{1}$ & 64.49 & 6.54 & 25.23 \\
\hline
\end{tabular}

Table 3: The characteristics of the organic matter in the $E s_{4}$ from the Well $F s_{2}$ in the Dongying depression. 


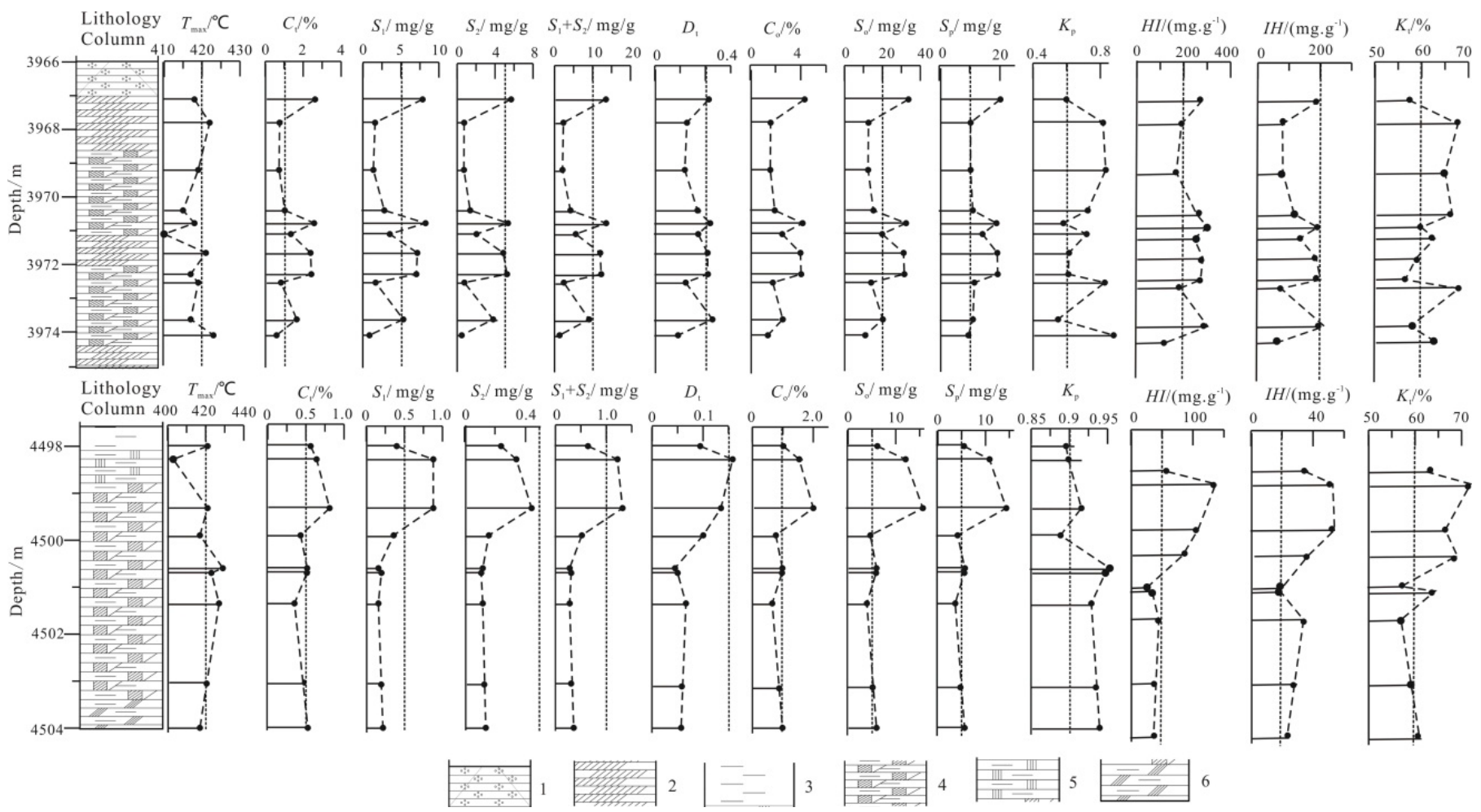

Figure 13: The hydrocarbon generation and expulsion from the source rocks in evaporated system of Es from the Well Fs2 in Dongying depression. 1-halite,gypsum; 2-salt rock; 3-mudstone; 4-salted-mudstone; 5-ypsumed-mudstone; 6-mudstone included salt

(Notes: $T_{\max }$, the supreme temperature in thermolysis; $C_{t}$, residual organic carbon content; $S_{1}$, residual dissolved hydrocarbon; $S_{2}$, pyrolysed hydrocarbon; $S_{1}+S_{2}$, residual potential of hydrocarbon generation; $D_{k}$, coefficient of residual hydrocarbon degraded; $C$, original organic carbon content; $S_{0}$, original capacity of hydrocarbon generation; $S_{p}$, amount of hydrocarbon expulsed; $K_{p}$, efficiency of hydrocarbon expulsion; $H I$, index of dissolved hydrocarbon; $I H$, hydrogen index; $K_{t}$, transformation ratio in thermolysis)

the bottom of the lake basin formed in a weak redox environment. The continuously conveying biological and organic substances from rivers provide material base for the hydrocarbon formation.

Generally, the formation and preservation of effect organic matter in salt lake is in an anaerobic environment (strong reducing environment). The high salinity in salt lake makes a halocline permanent hierarchy easy to form. The anoxic environment forms under bottom water characterized by high salinity, and the organic matter avoids the decomposition from oxidation, resulting in the formation of high quality source rocks [48]. This is reflected in the Chaerhan modern salt lakes in Qaidam basin: $1 \mathrm{~m}$ below the salt water is a permanent brine layers, in the depth of $3 \sim 4 \mathrm{~m}$ is strong reducing environment, where can form black mud.

Numerous continental salt basins in the eastern China show that at the second or third sedimentary cycle is the stage of source rocks formation. Many practice indicated that such a set of evaporite formation commonly was before the inevitable development of source rock. Peters et al. [32] pointed out that in barrier type of sedimentary basins; the content of organic matter was associated with the concentration of salt that deposited at the same time [49]. Tissot [50] observed that the organic matter content of rock salt is second only to clay (or shale) based on analysis on 108 pieces of rock salt [50].

Zhanhua depression is adjacent to the northeast of Dongying depression, thus the significance of evaporates for the organic matter in this depression can be compared. In the Zhanhua depression also develops the evaporate sediment combination up to $500 \mathrm{~m}$ on the upper $\mathrm{Es}_{4}$. Research shows the evaporite exists not only with source rock, but also with high quality one. In salt lake on saline lake, the salinity difference between surface and bottom layers could result in the salt transition layer and the division of upper and lower layers makes a long-rang delamination of salinity. Bottom water circulation is in an absolutely stagnant state and results in anoxia environment. This environment restrains the activity of benthon and makes a maximum preservation of sediment organic matters. Oil-source correlation shows that salt lake saline lake source rock is an important one in Zhanhua Depression and controls the formation and distribution of many pools.

\section{The significance of evaporites for the thermal maturation and oil generation}

The thermal conductivity of gypsum and cream salt layer is significantly higher than other rocks, and the heating rate is significantly lower than other rocks. Test of the rock from the Hk1 Well shows the average thermal conductivity of the gypsum halite layer dominated by salt rocks is $5.48 \mathrm{~W} / \mathrm{m} . \mathrm{K}$, and the average heat production rate of gypsum and salt rock are only $0.07 \mu \mathrm{W} / \mathrm{m}^{3}$ and $0.02 \mu \mathrm{W} / \mathrm{m}^{3}$ respectively (Table 4). Compared to the evolution of normal mature hydrocarbon source rock (mudstone and shale) the salt layer shows lower vitrinite reflectance $\left(R_{0}\right)$, and correspondly the paleogeothermal is lower than normal source rocks (Figure 14). Therefore, the existence of the halite layer makes the lower strata heat easily lose, lowers the temperature of the deep under the salt, suppresses the diagenesis, causes the diagenetic evolution of salt formation relatively lags behind the diagenetic evolution in the region without salt or gypsum, and correspondly 


\begin{tabular}{|c|c|c|c|c|c|c|c|}
\hline \multirow{2}{*}{ Samples } & & & & & \multirow{2}{*}{$\frac{a}{\left(\mu \mathrm{W} / \mathrm{m}^{3}\right)}$} & \multirow{2}{*}{$\frac{b}{(W / m \cdot K)}$} & \multirow{2}{*}{ Lithology } \\
\hline & & & & & & & \\
\hline S1 & 3431.07 & $\mathrm{Es}_{4}$ & 0.13 & 019 & 0.05 & 5.22 & salt rock \\
\hline S2 & 3433.08 & $\mathrm{Es}_{4}$ & 1.29 & 3.22 & 0.572 & 2.84 & \\
\hline S3 & 256 & $\mathrm{Es}_{4}$ & 0.065 & (1) & 0.024 & & salt rock \\
\hline S4 & 3437.11 & $\mathrm{Es}_{4}$ & 0.087 & 0.15 & 0.034 & 5.41 & $\begin{array}{l}\text { gypsum salt } \\
\text { rock }\end{array}$ \\
\hline S5 & 438.3 & $\mathrm{Es}_{4}$ & 0.029 & 0.05 & 0.012 & 5.76 & $\begin{array}{l}\text { gypsum salt } \\
\text { rock }\end{array}$ \\
\hline S6 & 40.4 & $E s_{4}$ & & & 09 & 28 & salt rock \\
\hline S7 & 3447.12 & $E s_{4}$ & 0.023 & 0.031 & 0.009 & 5.45 & salt rock \\
\hline S8 & & $E s_{4}$ & & & & 2.53 & mudstone \\
\hline s9 & & $\mathrm{Es}_{4}$ & 0.033 & 0.062 & 0.013 & 5.52 & salt rock \\
\hline $\mathrm{S} 10$ & 3977.04 & $E s_{4}$ & 4.75 & 20.6 & 2.77 & 2.16 & mudstone \\
\hline
\end{tabular}

a: radioactive heat generation of rocks; b: thermal conductivity

Table 4: The radioactive heat generation and thermal conductivity of rocks in the $\mathrm{Es}_{4}$ from the Well Hk1 in the Dongying depression.

prolong the oil generation window of the source rocks under salt layers.

\section{The significance of evaporites for the oil reservoir and} preservation

Salt-gypsum layer lead to the formation of overpressure sealing strip, which suppresses the compaction and is conducive to the preservation of primary pores. The inhibitory effect of abnormal high pressure on the thermal evolution of organic matter and hydrocarbon generation, make the release space of organic acids in the abnormal high pressure basin and the influence of organic acids on sandstone diagenesis greatly exceed the normal pressure basin. Organic acid and $\mathrm{CO}_{2}$ will release in the process of thermal evolution of organic matter, reduce the $\mathrm{pH}$ value of pore water, further strengthen the dissolution of minerals, make the cement and clastic particles in sandstone dissolve ,and promote the formation of secondary pore. The pressured seal formed by Salt-gypsum layers is beneficial to the growth of secondary porosity under salt and preserved. For example, in the Paleogene E $k$ ( Kongdian Member) and $E s_{4}$ there develop two overpressure belts and two interval depths (3398-3754m and 4052-4275.5m) for the development of secondary porosity accordingly, which are associated with the development of two halite layers respectively (Figure 15).

Figure 15 indicated that the development of secondary porosity under salt-gypsum layers was affected by rock types, structure and the development of primary pore at the same time. When primary pore relatively developed, acid formation water can smoothly enter between the particles and dissolve rock components.

The concentration layers of salt-gypsum in the Paleogene $\mathrm{Es}_{4}$ in Dongying depression forms a good regional cap rocks for the oil and gas below. This is indicated by the occurring of cracking gas and even industrial air flow in the Fs1, Fs2 and Fs3 Wells in the Minfeng sag in the north of Dong depression. The thick salt-gypsum layer becomes a good cover to prevent dissipation of oil and gas (Figure 16). In the saltgypsum layer in the north-central zone of Dongying depression there develops abnormal high pressure, and the local pressure coefficient reaches 2.05 . The existence of abnormal high pressure caused by the salt paste interval further enhances the sealing capability of the rocks.

\section{Conclusions}

This study showed the geochemical response in a co-sedimentary system by evaporites and mudstone in the $\mathrm{Es}_{4}$ of the Dongying Depression in Eastern China.
The total salinity was generally high. The type water of $\mathrm{CaCl}_{2}$ dominated. The $\mathrm{Al}, \mathrm{Mn}$, and $\mathrm{Ba}$ contents and the parameters of $\mathrm{V} / \mathrm{Ni}$ and $(\mathrm{Fe}+\mathrm{Al}) /(\mathrm{Ca}+\mathrm{Mg})$ showed low value responses. The $\mathrm{Na}, \mathrm{Ca}$, and $\mathrm{Mg}$ contents and the parameters of $\mathrm{Sr} / \mathrm{Ba}, \mathrm{Fe} / \mathrm{Mn}$, and $\mathrm{Sr} / \mathrm{Ca}$ showed high values. Sr content was remarkably high compared with that in the non-evaporite system. The distribution of mineral elements had visible characteristics of discretion and fluctuation, and mineral elements, except for $\mathrm{Na}$, had discrepancies in saline deposits and were enriched in adjacent mud.

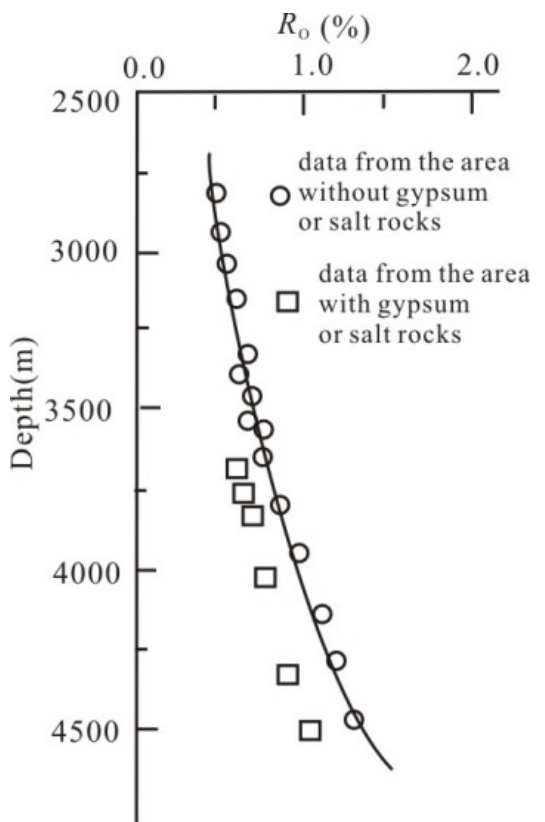

Figure 14: The distribution of Ro with depths in the area with/without evaporates in the Dongying depression.

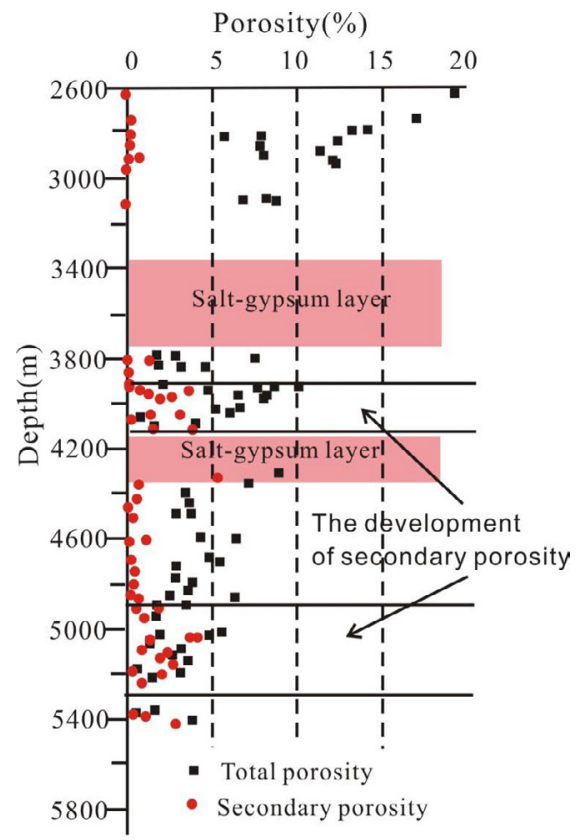

Figure 15: The distribution of total porosity and secondary porosity with depths in the Well Haoke1 in the Dongying depression. 


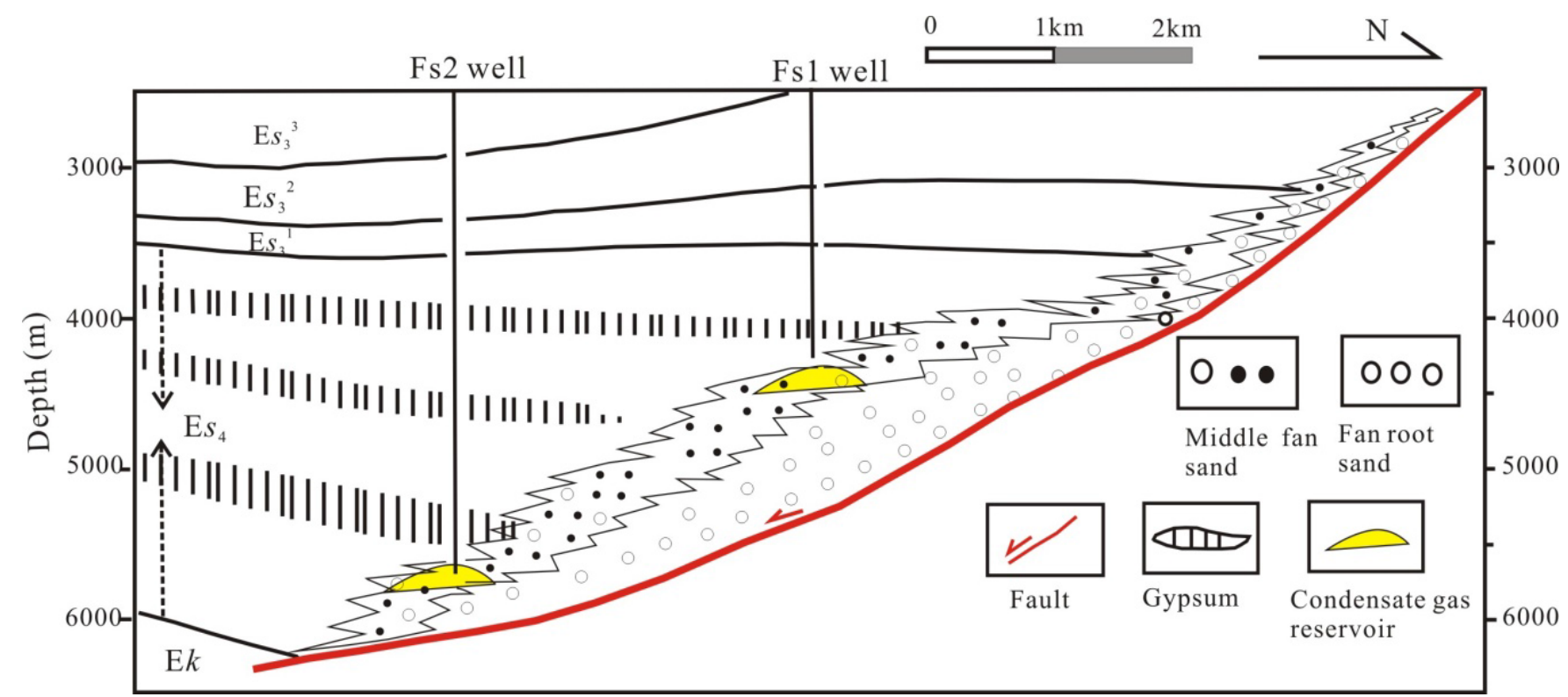

Figure 16: The geological section across the Wells Fs1 and Fs2 showing the relation of gypsum and cracking gas in the Lijin-Minfeng sag of Dongying depression.

A heavier isotope of carbon (high value of $\delta^{13} \mathrm{C}$ ) was displayed, and the value of $\delta^{13} \mathrm{C}$ for the high-maturity evaporite source rocks was significantly increased by thermal evolution and TSR reaction. High content of gammacerane and low value of $\mathrm{Pr} / \mathrm{Ph}$ were exhibited. The indicators $\mathrm{C}_{19} /\left(\mathrm{C}_{19}+\mathrm{C}_{23}\right)$ from terpanes and $\mathrm{C}_{24} / \mathrm{C}_{23}$ from tricyclic terpanes were lower, whereas $\mathrm{C}_{29} /\left(\mathrm{C}_{27}+\mathrm{C}_{28}+\mathrm{C}_{29}\right)$ from steranes were higher than those in the non-evaporite system in the Dongying Depression.

A distinct negative reversion of biomarker maturity parameters $\mathrm{C}_{29} \beta \beta /(\beta \beta+\alpha \alpha), \mathrm{C}_{29} 20 \mathrm{~S} /(20 \mathrm{~S}+20 \mathrm{R})$, and Ts/(Ts+Tm) was demonstrated, indicating that thermal evolution was restrained and retarded for the high content of gypsum-salt minerals. The co-sedimentary system can generate and expel hydrocarbon, and high maturation can reduce the capacity for these actions.

\section{Acknowledgments}

This study was supported by the National Natural Science Foundation of China (Grant No. 41272140 and 40802026) and Shandong Province Natural Science Foundation (Grant No. ZR2011DM004).

\section{References}

1. Trippetta F, Collettini C, Vinciguerra S, Meredith PG (2010) Laboratory measurements of the physical properties of Triassic Evaporites from Centra Italy and correlation with geophysical data. Tectonophysics 492: 121-132.

2. Trippetta F, Collettini C, Meredith PG, Vinciguerra S (2013) Evolution of the elastic moduli of seismogenic Triassic Evaporites subjected to cyclic stressing Tectonophysics 592: 67-79.

3. Trippetta F, Collettini C, Barchi MR, Lupattelli A, Mirabella F (2012) A multidisciplinary study of a natural example of a $\mathrm{CO} 2$ geological reservoir in central Italy. International Journal of Greenhouse Gas Control 12: 72-83.

4. Carminati E, Corda L, Mariotti G, Scifoni A, Trippetta F (2013) Mesozoic Synand Postrifting Evolution of the Central Apennines, Italy: The Role of Triassic Evaporites. The Journal of Geology 121: 327-354.

5. Tissot BP, Welte DH (1978) Petroleum Formation and Occurrence. Springer Berlin Heidelberg Germany.

6. Sinninghe Damste JS, Kenig F, Koopmans MP, Koster J, Schouten S, et al (1995) Evidence for gammacerane as an indicator of water column stratification. Geochim Cosmochim Acta 59: 1895-1900.
7. Waples DW (1983) Reappraisal of anoxia and organic richness, with emphasis on Cretaceous of North Atlantic. AAPG Bulletin 67: 963-978.

8. Hofmann P, Leythaeuser D, Carpentier B (1993) Palaeoclimate controlled accumulation of organic matter in Oligocene evaporite sediments of the Mulhouse basin. Org Geochem 20: 1125-1138.

9. Qiang J, Guang-you Z (2006) Progress in Research of Deposition of Oil Source Rocks in Saline Lake and Their Hydrocarbon Generation. Acta Metallurgica Sinica 12: 483-492.

10. Zhonghong C, Ming Z, Qiang J (2004) An Investigation on Generation and Expulsion of Hydrocarbon from Source Rocks of the Shahejie Formation in the Well Niu-38, Dongying Depression. Chinese Journal of Geology 39: 356-366.

11. Zhonghong C, Ming Z, Qiang J (2006) teristics of the source rocks in fluctuation from lake facies: an example from the Well Niu-38 in the Dongying Depression, China. Journal of Lake Sciences 1: 29-35.

12. Zhonghong C, Ming Z (2008) Mechanism of overpressured fluid compartment and its controlling on hydrocarbon migration and accumulation in faulted lacustrine basin:A case study from the Dongying Sag,Bohai Bay Basin. Chinese Journal of Geology 43: 50-64.

13. Guang-you Z, Qiang J, Jin-xing D, Shui-chang Z, Lin-ye Z, et al. (2004) Investigation on the Salt Lake Source Rocks for Middle Shasi Column of Dongying Depression. Acta Metallurgica Sinica 10: 257-266.

14. Mango FD (1991) The stability of hydrocarbons under the time-temperature conditions of petroleum genesis. Nature 352: 146-148.

15. Tijani MN (2004) Evolution of saline waters and brines in the Benue-Trough Nigeria. Appl Geochem 19: 1355-1365.

16. Zhong-hong C, Ming Z (2007) Correlation between inorganic elements and abnormal vitrinite reflectance in lacustrine source rocks. Geochimica 36: 275 278

17. Hardie LA, Eugster HP (1970) The evolution of closed-basin brines. Minera Soc Am Spec Pap 3: 273-290.

18. Eugster HP (1980) Geochemistry of Evaporitic Lacustrine Deposits. Annu Rev Earth PI Sc 8: 35-63.

19. Warren JK (2010) Evaporites through time: Tectonic, climatic and eustatic controls in marine and nonmarine deposits. Earth-Sci Rev 98: 217-268.

20. Yangming Z, Huanxin W, Aiguo S, Digang L, Dehua P (2005) Geochemical characteristics of Tertiary saline lacustrine oils in the Western Qaidam Basin, northwest China. Appl Geochem 20: 1875-1889.

21. Chun-rong L, Kai-yuan C (2004) The Application of C and O Isotope Analyse 
Citation: Chen ZH, Zhang JQ, Wang L, Zha M (2013) Geochemistry of Evaporites in Lacustrine Basin, Dongying Depression, Bohai Bay Basin, China. J Pet Environ Biotechnol 4: 156. doi:10.4172/2157-7463.1000156

Page 15 of 15

in Sediment Environment of Qianjiang Saline Lake. Natural Gas Geoscience 15: $320-322$

22. Zhenheng C, Zhonghong C, Yuti Z, Jun P, Zhenhua J, et al. (2007) An Investigation on the Geochemical Characteristics of Crude Oil from Wenliu Area in the Dongpu Sag,Bohai Bay Basin. Petroleum Geology \& Experiment 29: $178-187$

23. Schouten S, Hartgers WA, Lòpez JF, Grimalt JO, Sinninghe Damsté JS (2001) A molecular isotopic study of 13C-enriched organic matter in evaporitic deposits: recognition of CO2-limited ecosystems. Org Geochem 32: 277-286.

24. Murray AP, Summons RE, Boreham CJ, Dowling LM (1994) Biomarker and $n$-alkane isotope profiles for Tertiary oils: relationship to source rock depositional setting. Org Geochem 22: 521-542.

25. Popp BN, Laws EA, Bidigare RR, Dore JE, Hanson KL, et al. (1998) Effect of phytoplankton cell geometry on carbon isotopic fractionation. Geochim Cosmochim Ac 62: 69-77.

26. Zhu GY, Zhang SC, Liang YB, Dai JX, Li J (2005) Alteration of thermochemical sulfate reduction to hydrocarbons. Acta Petrolei Sinica 26: 48-52.

27. Ma YS, Cai XY, Li GX (2005) Basic Characteristics and concentration of the Puguang gas field in the Sichuan Basin. Acta Geologica Sinica 79: 858-865.

28. Zhi-Yong C, Qi-Ming L, Bin X (2007) Study on the Mechanism and Accumulation Effect of Thermochemical Sulfate Reduction in Northeast Area of Sichuan Absin. Natural Gas Geoscience 18: 743-749.

29. Haven HLT, Leeuw JWD, Rullkötter J, Sinninghe Damsté JS (1987) Restricted utility of the pristane/phytane ratio as a palaeoenvironmental indicator. Nature 330: 641-643.

30. Schwark L, Vliex M, Schaeffer P (1998) Geochemical characterization of Malm Zeta laminated carbonates from the Franconian Alb, SW-Germany (II). Org Geochem 29: 1921-1952

31. Peters KE, Walters CC, Moldowan JM (2005) The Biomarker Guide: Biomarkers and isotopes in petroleum systems and Earth history, Volume 2. Cambridge University Press UK.

32. Peters KE, Moldowan JM (1993) The Biomarker Guide: Interpreting Molecular Fossils in Petroleum and Ancient Sediments. Prentice Hall Englewood Cliffs NJ USA.

33. Wang TG (2002) A contribution to some sedimentary environmental biomarkers in crude oils and source rocks in China. Geological Review 48: 256-262.

34. Seifert WK, Moldowan JM (1979) The effect of biodegradation on steranes and terpanes in crude oils. Geochim Cosmochim Ac 43: 111-126.

35. Seifert WK, Moldowan JM (1981) Paleoreconstruction by biological markers Geochim Cosmochim Ac 45: 783-794.

36. Chen Z, Zha M, Jin Q, Ren Y (2011) Distribution of sterane maturity parameters in a lacustrine basin and their control factors: A case study from the Dongying Sag, East China. Petroleum Science 8: 290-301.

37. Tuo JC, Huang XZ, Ma WY (1994) The Lagging phenomenon of the petroleum generation in carbonate rocks. Petroleum Exploration and Development 21 : $1-5$

38. Guiyu Z, Shuyuan L, Luofu L (2005) A Study on Characteristics and Kinetics of Catalytic Degradation from Kerogen in Carbonate Rocks. Chinese Journal of Geology 40: 47-54.

39. Xie QL, Zhou ZY, Lu MY (2000) Organic matter enclosed in carbonate minerals; a kind of important hydrocarbon producing matter. Acta Mineralogica Sinica 20: 59-62.

40. Yuan J, Qin K (2001) Characteristics of Evaporite Generated in Deep Water of Sha-4 Member in Dongying Sag. University of Petroleum China 25: 9-11.

41. Chuanlian L, Quanhong Z, Pinxian W (2001) Paleolimnological Significance of Carbon and Oxygen Isotopic Ratios of Ostracoda from Oil Source Rocks in Dongying Depression. Earth Science 26: 441-445.

42. Chen FL, Zhu H, Li HT (2000) Partition of sequence strata and discussion about salt-rock resource in Shahejie formation of Eogene, Dongpu depression. Acta Sedimentologica Sinica 18: 384-388

43. You-liang J, Jian-hui F, Sheng-lang W, Hong-an Z (2003) High Frequency Lake-Level Change of 3rd Member of Shahejie Formation and Prediction of Lowstand Sand Body in Dongpu Depression. Acta Metallurgica Sinica 9: 99112

44. Laiyi R, Guifang L, Zhiqing Z, Xingwu W (2000) Early Tertiary marine transgression in Dongpu depression. Acta Palaeontologica Sinica 39: 553-557.

45. Qiang J, Xinghan H (1985) Studies on the Origin of the Early Tertiary Salt Lake Dongpu Depression_A Postulated Deep Water Model. Journal of the University of Petroleum 9: 1-11.

46. Zhu YM, Su AG, Liang DG (2003) Distribution characterization and origin of n-alkanes in saline lacustrine source rocks of Qaidam Basin. Geochimica 32 117-123.

47. Qiang J, Ming Z (2000) Co-Sedimentation of Tertiary Evaporites and Oil Source Rocks in the Western Qaidam Basin. Chinese Journal of Geology 35: 465-473.

48. Taberner C, Cendón DI, Pueyo JJ, Ayora C (2000) The use of environmental markers to distinguish marine vs. continental deposition and to quantify the significance of recycling in evaporite basins. Sediment Geol 137: 213-240.

49. Rohrback BG, Peters KE, Kaplan IR (1984) Geochemistry of artificially heated humic and sapropelic sediments; II, Oil and gas generation. AAPG Bulletin 68 961-970.

50. Tissot BP (1984) Recent Advances in Petroleum Geochemistry Applied to Hydrocarbon Exploration. AAPG Bulletin 68: 545-563. 